"This is an Accepted Manuscript of an article published by Taylor \& Francis in Information \& Communications Technology Law, 23:2, 81116, on 12 June 2014, available online:

https://doi.org/10.1080/13600834.2014.921387 


\title{
Brazil's Implementation of TRIPS Flexibilities: Ambitious Missions, Early Implementation, and the Plans for Reform
}

\begin{abstract}
Jae Sundaram*
Abstract:

The flexibilities introduced in the TRIPS Agreement were aimed at providing the developing countries with the option to adopt suitable measures to address access to patent protected pharmaceutical products. The flexibilities include the grant of compulsory licenses, exceptions to the exclusive right conferred by patent, allowing for parallel imports, and defining the criteria of patentability to achieve the goal of public health. While these flexibilities are available to all developing countries, only a few have implemented the flexibilities into their patent legislation. This article examines the TRIPS compliant patent laws introduced in Brazil in the post-TRIPS era. It will be argued that the TRIPS Agreement was implemented too soon in Brazil, and the TRIPS flexibilities, although available had not been fully utilised due to pressure from transnational pharmaceutical corporations backed by developed countries, fear of exclusion from major trading blocs, and also due to a gap in the knowledge economy. It will also be argued that the WTO did not create a level playing field in the TRIPS negotiation in the lead up to the entry into force of the Agreement in 1995, which effectively handed over the advantage to the developed countries, thereby creating a two tier system in the intellectual property rights arena, and making it impossible for developing countries and least developed countries to achieve the objective of access to affordable medicines.
\end{abstract}

Keywords: TRIPS; Brazil; patents; compulsory-licensing; bolar-exception; evergreening PART 1

\section{Introduction}

Patent rights fall under the broad spectrum of intellectual property rights, and have a very high commercial value in a consumer driven economy, where right holders seek to enforce their rights globally. Patent right is a monopoly right granted to a person who has invented a new and useful product, and prohibits the unauthorised exploitation of the patented product by third parties. ${ }^{1}$ The justification for an exclusive monopoly right is strongly predicated on the premise that rewarding the inventor for the skill and effort expended will encourage innovation, although no clear evidence is available to lend support this rhetoric. ${ }^{2}$ Some have argued that conferring monopoly rights on life-saving drugs should be excluded from the purview of patent laws as it leads to the abuse of the monopoly by the patent holders. The current study is

\footnotetext{
*Senior Lecturer in Law, Law School, University of Buckingham. Email: jae.sundaram@buckingham.ac.uk. 1 "A patent is the right granted to an inventor by a State, or by a regional office acting for several States, which allows the inventor to exclude anyone else from commercially exploiting his invention for a limited period, generally 20 years," WIPO, 'Fields of Intellectual Property Protection,'WIPO Intellectual Property Handbook: Policy, Law and Use (WIPO 2008 Reprint) 17, Publication No. 489(E), ISBN: 978-92-805-1291-5 $<$ http://www.wipo.int/export/sites/www/freepublications/en/intproperty/489/wipo_pub_489.pdf $>$ accessed 18 January 2014.

2 S Basheer, 'India's First Compulsory License: Patents vs. Public Health?' IP Osgoode (2 April 2012) $<$ http://www.iposgoode.ca/2012/04/india\%E2\%80\%99s-first-compulsory-license-patents-vs-public-health/> accessed 23 October 2013. See also C Chien, 'Cheap Drugs at What Price to Innovation: Does Compulsory Licensing of Pharmaceuticals Hurt Innovation?’ Berkeley Tech LJ Vol.18 (2003) 853, 896-907. The author argues that the studies available only indicate that licenses do not have any significant demonstrable effects on the rate and pace of innovation.
} 
concerned with international pharmaceutical patent rights protection and the response of Brazil, a developing country, to the implementation of the Trade-Related Aspects of Intellectual Property Rights (TRIPS) flexibilities into its national legislation. The laws and the allied policies of Brazil are chosen for the study as the country falls under the category of a developing country, ${ }^{3}$ and for also being seen as potential growth markets by the global pharmaceutical industry. Brazil presents an ideal choice for study of its TRIPS compliant legislation, and the implementation of TRIPS flexibilities due to its socio-economic conditions, and also due to its historical background in just having emerged from over two decades of military rule in the last quarter of the $20^{\text {th }}$ century. Brazil along with Russia, India, and China are referred to as the BRIC economies, ${ }^{4}$ has the domestic need and necessity to implement the flexibilities, as a large number of its population is in dire need of generic medicines (for instance, antiretroviral drugs for HIV/AIDS) for frontline treatment, apart from the requirement to comply with the TRIPS Agreement. There is also clear evidence that Brazil has implemented the TRIPS flexibilities to meet both its domestic need and international commitments.

The study will present the opportunity to analyse the rationale behind the specific provisions of the TRIPS compliant patent legislation, shedding light on the socio-economic and legal needs of Brazil, and raise the query if external factors, such as free trade agreements (FTAs), pressure from multinational pharmaceutical corporations backed by developed countries, and political pressure, had influenced the implementation and the legislative process. The study will also analyse if the measures taken in response to the TRIPS' requirement had improved the conditions on the ground, and if it had facilitated and, or improved access to affordable medicines to demonstrate the objectives and promise made under the TRIPS Agreement. The work is organised into four parts, with the first part providing the introduction, and the second part presenting a contextual analysis of TRIPS Agreement, its genesis, and the introduction of flexibilities into the Agreement. The third part presents the country specific analysis of TRIPS flexibilities implemented into the national legislations, and the fourth part considers the outcomes of the analysis and concludes the study. The fourth part will also suggest such ways to address the inequalities in access to affordable medicines created in developing and least developed countries (LDCs) through the introduction of an international intellectual property rights regime.

\section{PART 2}

\section{TRIPS Agreement - Genesis \& Entry}

The Agreement on Trade-Related Aspects of Intellectual Property Rights (TRIPS) is one of the covered agreements of the World Trade Organization (WTO) $)^{5}$ that mandates a global minimum standard for intellectual property rights protection on all member countries. The TRIPS Agreement, drafted at the behest of patent right holders and backed by developed countries, ${ }^{6}$ is one of the most controversial agreement of the WTO system, as it has far-reaching implications on international intellectual property rights protection and access to medicines in developing countries and LDCs. The Agreement obligates countries to grant product patents for a period of 20 years in all fields of technology, including pharmaceuticals, and sets a

\footnotetext{
${ }^{3}$ The WTO has not fixed formal criteria for a Member State to be classified as a developing country, but Member States self-ascribe to this category.

${ }^{4}$ The acronym BRIC was coined by the economist Jim O'Neill in a 2001 paper entitled 'Building Better Global Economic BRICs.' The acronym refers to Brazil, Russia, India, and China as emerging advanced economies, away from the developed G7 economies.

${ }^{5}$ The TRIPS Agreement is one of the covered agreements of the WTO and came into force on 1 January 1995.

${ }^{6}$ See generally, SK Sell, Private Power, Public Law: The Globalization of Intellectual Property Rights (Cambridge, 2003).
} 
minimum standard for the protection of intellectual property. ${ }^{7}$ Under the Agreement all Member States are required to comply with pre-existing international agreements on intellectual property, and to ensure equal treatment to citizens of all Member States. ${ }^{8}$ It also requires Member States to establish legal and administrative procedures within their jurisdictions to ensure effective protection to both domestic and international patent holders' rights, besides establishing appropriate mechanism for redress in the event of any infringement of patent rights. Failure to embody changes to national laws will be seen as a violation of the TRIPS Agreement and be liable for challenge by the trading partners before the WTO's dispute settlement system. Although the TRIPS Agreement does not aim to achieve uniform laws through its implementation, it creates rights for producers of intellectual property and obligations for the users, but speaks very little about the rights of users of intellectual property, ${ }^{9}$ which is uncharacteristic of an international agreement created and administered by a world governing body. To complicate matters further, the minimum standards to be followed by Member States are often undefined leaving room for variations in national legislations.

Before the creation of the WTO and the entry into force of the TRIPS Agreement, international intellectual property rights were regulated through a patchwork of treaties administered by the World Intellectual Property Organization (WIPO), including the Paris Convention on Industrial Property and the Berne Convention on Literary and Artistic Works. ${ }^{10}$ The conventions administered by the WIPO were focused on procedures to streamline patent applications in countries already providing patents and to ensure equal treatment of foreign applicants alongside domestic ones. ${ }^{11}$ Developing countries and least developed countries (LDCs) have had little or no involvement in the development of the above core international IP treaties, as most of them were negotiated in the colonial era. ${ }^{12}$ Developing country concerns about international intellectual property regulations started to emerge only in the post-colonial era, culminating in a North-South stand-off on reform of the international IP system in the 1970 s and 1980s. ${ }^{13}$ It is to be borne in mind that the TRIPS Agreement was negotiated at a time when there was a deadlock between developed countries on the one hand, and developing countries and LDCs on the other hand over the revision of the Paris Convention for the Protection of Industrial Property, before the WIPO. ${ }^{14}$ Also, a number of developing countries

\footnotetext{
${ }^{7}$ Under the Paris Convention for Protection of Industrial Property 1883, contracting parties were permitted to exclude patent protection in certain sectors such as pharmaceuticals, and permitted to determine the duration of patent rights, and grant compulsory license for a variety of reasons. Most of these flexibilities are not available under the TRIPS Agreement.

${ }^{8} \mathrm{CM}$ Ho, 'An Introduction to TRIPS' in CM Ho, Access to Medicine in Global Economy: International Agreement on Patents and Related Rights (Oxford, 2011) 57.

${ }^{9}$ See, e.g., A Kur and HG Ruse-Khan, 'Enough is Enough - The Notion of Binding Ceilings in International Intellectual Property Protection' Max Planck Institute for Intellectual Property, Competition \& Tax Law, Research Paper Series No. 09-01, (2008) < http://ssrn.com/abstract=1326429> accessed 27 February 2014.

10 UNCTAD-ICTSD, 'Resource Book on TRIPS and Development' (2005) 3.

${ }^{11}$ Paris Convention for the Protection of Industrial Property, art 3, Mar. 20, 1883, revised July 14, 1967,21 U.S.T.1583, 828 U.N.T.S. 305 (requiring equal treatment for foreign applicants); Patent Cooperation Treaty, June 19,1970, 28.7 U.S.T. 7645, 1160 U.N.T.S. 232 (providing a streamlined process for submitting patent applications in multiple jurisdictions). See also Ho (n 6).

${ }^{12} \mathrm{C}$ Deere, The Implementation Game: The TRIPS Agreement and the Global Politics of Intellectual Property Reform in Developing Countries (Oxford, 2009) 8.

13 Ibid.

${ }^{14}$ The 1980's and 1990s saw the shift in the administration of international intellectual property rights from the WIPO to the GATT through the lobbying of transnational corporations (TNCs). The TNCs were convinced that renegotiation of the Paris Convention under the aegis of the WIPO will never give them the level of protection they sought. See also, PK Yu, 'Currents and Crosscurrents in the International Intellectual Property Regime' Loy LA L Rev 38(1) (2004) 323, 357-58.
} 
that sought membership at the WTO were not granting patent monopolies for pharmaceutical products $^{15}$ at the time when the Uruguay Round ${ }^{16}$ of negotiation was taking place. ${ }^{17}$

Developing countries, led by India, Brazil, and Argentina, were strongly opposed to the proposal as they were of the firm view that the GATT mandate did not allow for the discussion of substantive issues on intellectual property, and that it was the World Intellectual Property Organization (WIPO) that had the institutional competence to discuss such issues. ${ }^{18}$ In July 1989, India, one of the developing countries, submitted a detailed paper at the negotiations expressing the developing countries' strong opposition to the inclusion of intellectual property rights to the GATT agenda. ${ }^{19}$ Although the paper presented by India at the negotiations was debated, ${ }^{20}$ it did not have the desired effect, as towards the latter half of 1989 and the beginning of 1990 almost all developing countries were constrained to change their position on the inclusion of intellectual property rights to the GATT agenda. ${ }^{21} \mathrm{With}$ little or no opposition from the developing countries at the negotiations, ${ }^{22}$ the debate on the inclusion of intellectual property rights into the GATT agenda came to an end, paving the way for the entry of the TRIPS Agreement. ${ }^{23}$

${ }^{15}$ CM Correa, 'Intellectual Property Rights and Inequalities in Health Outcomes' in Ronald Labonté, et al. (eds), Globalization and Health: Pathways, Evidence and Policy (Routledge 2009) 266.

${ }^{16}$ The Uruguay Round was the eighth round of multilateral trade negotiations, and took over seven years to complete. Launched in Punta Del Este in September 1986, it was finally concluded in Geneva, in January 1995 with the creation of the World Trade Organization. WTO, 'The Uruguay Round' $<$ http://www.wto.org/english/thewto_e/whatis_e/tif_e/fact5_e.htm> accessed 12 February 2014.

${ }^{17}$ CM Correa, 'Patent Rights' in CM Correa and AA Yusuf(eds), Intellectual Property and International Trade: The TRIPS Agreement (2nd edn, Kluwer 2008) 227, 229.

${ }^{18} \mathrm{~J}$ Watal, Intellectual Property Rights in the WTO and Developing Countries, (Kluwer Law International 2001) 21. See generally P Drahos, 'Developing Countries and International Intellectual Property Standard-Setting' (2002) UK Intellectual Property Rights Commission Study Paper No 8 $<$ http://www.iprcommission.org/papers/pdfs/study_papers/sp8_drahos_study.pdf $>$ accessed 2 October 2013.

${ }^{19}$ UNCTAD-ICTSD, 'Resource Book on TRIPS and Development' (2005) 6.

${ }^{20}$ UNCTAD-ICTSD, 'Resource Book on TRIPS and Development' (2005) 7. India had all along argued that any principle or standard relating to IPRs should be carefully tested against the needs of developing countries, and that it would be inappropriate to focus the discussions on the protection of the monopoly rights of the owners of intellectual property, when almost 99 percent of the patents were owned by industrialised nations. It urged that the group focus on restrictive and anti-competitive practices of the owners of IPR and evolve standards and principles for their elimination to avoid distortion of trade. It also stressed that substantive standards on intellectual property were more in the realm of socio-economic, industrial and technological development, especially in the case of developing countries.

${ }^{21}$ The shift came about due the coercive strategies adopted by the United States, and as a result India found itself isolated in the negotiations. RC Bird \& DR Cahoy, 'The Emerging BRIC Economies: Lessons from Intellectual Property Negotiation and Enforcement' 5 Nw J Tech \& Intell Prop 1 (2007) 400, 403-04; J Watal (n 14). For a detailed account of the TRIPS negotiations, see DJ Gervais, 'Intellectual Property, Trade \& Development: The State of Play' Fordham L Rev 74(2) (2005) 505.

${ }^{22}$ GK Foster, 'Opposing Forces in a Revolution in International Patent Protection: The U.S. and India in the Uruguay Round and Its Aftermath' 3 UCLA J Int'l L \& Foreign Aff (1998) 283, 317. See also generally, P Drahos, 'Developing Countries and International Intellectual Property Standard-Setting' (2002) UK IPR Commission Paper $8<$ http://www.iprcommission.org/papers/pdfs/study_papers/sp8_drahos_study.pdf $>$ accessed 2 October 2013. The author argues that developing nations had comparatively far less influence on outcomes in the international intellectual property standard-settings, at both pre-TRIPS and post-TRIPS negotiations. The author attributes the weak position of the developing nations to the use of coercive tactics by the United States (US) and the European Union (EU), who had all along stressed the need for excessively high global standards on intellectual property protection. See also J Sundaram, 'India's Trade-Related Aspects of Intellectual Property Rights Compliant Pharmaceutical Patent Laws: What Lessons for India and Other Developing Countries?' I \& Comm T L Vol. 23 Issue 1 (2014) 1-30.

${ }^{23}$ See also SK Sell, 'Cat \& Mouse: Forum-Shifting in the Battle over Intellectual Property Enforcement' (Draft, prepared for American Political Science Association Meeting, September 3-6, 2009, Toronto) $<$ http://papers.ssrn.com/sol3/papers.cfm?abstract_id=1466156> accessed 12 January 2014. 


\subsection{TRIPS Flexibilities and the Implementation Game}

There was a growing concern amongst the developing countries that the intellectual property right standards sought to be introduced through the TRIPS Agreement could severely restrict access to essential medicines ${ }^{24}$ for their citizens, and also impede their efforts to control diseases including HIV/AIDS, tuberculosis and malaria. Some feared that the extended intellectual property rights protection for pharmaceutical patents was likely to increase dependency on multinational pharmaceutical companies and affect the developing and developed countries severely, as essential medicines will become unaffordable and beyond their reach. The developing countries position was that the TRIPS Agreement did not limit their sovereign powers when addressing domestic health crises such as HIV/AIDS, while developed countries like the US and Switzerland (both holding a number of pharmaceutical patents) assuming the stance that the only flexibility afforded under the Agreement was its staggered implementation in certain cases. ${ }^{25}$ Against this backdrop, the Council for TRIPS ${ }^{26}$ agreed to deal specifically with the relationship between the TRIPS Agreement and public health in developing countries.

In June 2001, for the first time, the Council for TRIPS considered in detail the relationship between public health and TRIPS, ${ }^{27}$ which to some degree helped move in the direction of a special declaration on the subject. The Doha Declaration on TRIPS and Public Health $^{28}$ (Doha Declaration) made on November 2001, helped in resolving some of the above concerns and other divergent views held by the member states on the application and ambit of the TRIPS Agreement. ${ }^{29}$ The concerns raised by the developing countries regarding the implications of the TRIPS Agreement on public health were reflected in the adoption of the Doha Declaration on the TRIPS Agreement and Public Health. The Doha Declaration proclaimed that each Member had the right to grant compulsory licenses, and to determine the grounds for the grant and also what constituted a national emergency. This Declaration and the 2003 Decision on Implementation of Paragraph $6^{30}$ of the TRIPS Agreement recognised the right of a country to gain access to medicines. Also, a lack of clarity and consensus on the TRIPS flexibilities had hampered the efforts to widen access to antiretroviral (ARVs) treatment in developing and least developed countries. ${ }^{31}$

The Doha Declaration went a long way to clarify the scope of the TRIPS Agreement, besides also providing interpretative guidance on the policy flexibilities embodied in the TRIPS

\footnotetext{
${ }^{24}$ Access to essential medicines is recognised as an indispensable part of the right to health, and is viewed as a non-delegable obligation on the part of the State, and cannot be violated based on lack of available resources. 'The Selection and Use of Essential Medicines' WHO Technical Report Series 914 (2002) $<$ http://apps.who.int/medicinedocs/pdf/s4875e/s4875e.pdf $>$ accessed 12 January 2014.

${ }^{25}$ Sundaram (n 22).

${ }^{26}$ The Council for TRIPS is charged with the monitoring of WTO Members' compliance with their obligations under TRIPS. The legal basis for the establishment of the Council is found in Article IV.5 of the WTO Agreement, which stipulates that the Council "shall oversee the functioning" of TRIPS Agreement. See also UNCTAD-ICTSD (n 39) 739.

27 The World Health Assembly had in 1996 examined the relationship between public health and the TRIPS Agreement, as it was mandated to report on the impact of the work of the WTO with respect to national drug policies and essential drugs. This was addressed in a resolution on the Revised Drug Strategy, Resolution WHA 49.14 (25 May 1996).

${ }^{28}$ World Trade Organization, Declaration on the TRIPS Agreement and Public Health, WT/MIN(01)/DEC/2, adopted on 20 November $2001<\mathrm{http}$ //www.wto.org/english/thewto_e/minist_e/min01_e/mindecl_trips_e.pdf $>$ accessed 28 March 2013.

${ }^{29}$ JT Gathii, 'The Legal Status of Doha Declaration on TRIPS and Public Health Under the Vienna Convention on the Law of Treaties' Harv JL \& Tech (Spring 2002) 292, 293.

${ }^{30}$ World Trade Organization, Implementation of Paragraph 6 of the Doha Declaration on the TRIPS Agreement and Public Health, WT/L/540 and Corr.1 (2003).

${ }^{31}$ DOHA+10, TRIPS Flexibilities and Access to Antiretroviral Therapy: Lessons from the Past, Opportunities for the Future, UNAIDS, ISBN: 978929173914 (2011) 6.
} 
Agreement. ${ }^{32}$ Despite the above positives derived from the Doha Declaration ${ }^{33}$ and UN commitments in the form of Millennium Goals, ${ }^{34}$ much is left to be desired,,${ }^{35}$ as the developing countries and LDCs still face big challenges in the implementation of the flexibilities due to increased intellectual property protection introduced under the TRIPS Agreement. ${ }^{36}$ Nevertheless, the Doha Declaration's impact has been widespread amongst developing countries, affecting their health policies and in particular their pharmaceutical patent legislation. It is worth noting here that some developing countries have used the TRIPS flexibilities to produce and purchase generic antiretroviral medications. There is also evidence of donor countries now permitting the use of their funds to procure generic antiretroviral medications for least developed countries. ${ }^{37}$ The use of the flexibilities afforded under the Doha Declaration came for severe criticism from global pharmaceutical companies who were acting through their national governments, as they fiercely opposed the practical implementation of the TRIPS flexibilities, in the case of Brazil and Thailand in 2007-2008. ${ }^{38}$

While the developing countries were eager to join the WTO and made to sign up to the TRIPS Agreement, most were in for a rude shock as the trade-off agreed between the developed nations and the developing nation could not materialise. ${ }^{39}$ To a great extent the gap in the knowledge economy between the developed and the developing countries (North-South divide) contributed to their ignorance of the TRIPS Agreement's implication and the flexibilities offered therein. ${ }^{40}$ Although it is arguable that all of the parties were given the opportunity to participate in the negotiations leading to the TRIPS Agreement during the Uruguay Round of talks, the same may not hold good as the voice of the developing countries were effectively silenced through a series of manoeuvrings by the patent holding developed countries led by the

${ }^{32}$ Ibid.

${ }^{33}$ The Doha Declaration left unresolved the issue on how to export products manufactured under a compulsory license to countries without domestic production capacity. It also did not address the promise of increased $R \& D$ in exchange for higher levels of IP protection, which was used as a bargaining chip by the developed countries during TRIPS negotiations. EFM't Hoen, The Global Politics of Pharmaceutical Monopoly Power: Drug Patents, Access, Innovation and the Application of the WTO Doha Declaration on TRIPS and Public Health (ABM, The Netherlands, 2009) 2-3.

${ }^{34}$ The United Nations Millennium Development Goal (UN MDG), Target 8.E states that in cooperation with pharmaceutical companies, to provide access to affordable essential drugs in developing countries. United Nations, 'Millennium Development Goals and Beyond 2015'<http://www.un.org/millenniumgoals/global.shtml> accessed 2 February 2014.

${ }^{35}$ According to 2008 figures released by the WHO, approximately a third of the people worldwide lack access. Further, the high prices of essential medicines act as a barrier in the treatment of millions.

36 Deere (n 12). See also United Nations, 'The Millennium Development Goals Report 2013' $<$ http://www.un.org/millenniumgoals/pdf/report-2013/mdg-report-2013-english.pdf $>$ accessed 2 February 2014. Interestingly, the report does not list any entries under $8 \mathrm{E}$ of the Goals, which is aimed at providing access to affordable essential drugs in developing countries.

${ }^{37}$ The value of donor-funded developing country ARV market has had a dramatic annual growth in recent times. By 2008, Indian generic ARVs accounted for $65 \%$ of the total value (US\$463 million) of ARV purchases reported. See B Waning, E Diedrichsen \& S Moon, 'A Lifeline to Treatment: The Role of Indian Generic Manufacturers in Supplying Antiretroviral Medicines to Developing Countries' (2010) Journal of International AIDS Society $<$ http://www.biomedcentral.com/content/pdf/1758-2652-13-35.pdf $>$ accessed 5 February 2014.

38 't Hoen (n33).

${ }^{39}$ RC Dreyfuss, 'The Role of India, China, Brazil and Other Emerging Economies in Establishing Access Norms for Intellectual Property and Intellectual Property Law Making' IILJ Working Paper 2009/5, NYU School of Law, (2009) $4<$ http://ssrn.com//aol3/papers.cfm?abstract=11442785> accessed 28 January 2014. According to the author's analysis the trade-off was access to foreign markets in exchange for raising domestic intellectual property levels, which was a losing proposition.

${ }^{40}$ Ibid. 
US, EU, Switzerland and Japan. ${ }^{41}$ The tactics included both economic pressure and the fear of exclusion from any future trade and investment opportunities. ${ }^{42}$

\section{PART 3}

\section{Brazil Background: Exploration, History \& Constitution}

Brazil $^{43}$ was under Portuguese colonial rule for over three centuries, between $1500^{44}$ and $1823,{ }^{45}$ during which period the Civil law legal system was introduced in stages by the colonial powers. In the later part of the $15^{\text {th }}$ Century and during the $16^{\text {th }}$ Century, the Portuguese had to compete with the Spanish in the occupation and colonisation of the New World, which included the territory which came to be identified as Brazil. The Portuguese exploration of the continent came only eight years from Columbus's famous first voyage, and required the intervention from the Papacy to resolve the disputes amongst the European neighbours on the administration and colonisation of the new territories in South America. ${ }^{46}$ In 1532 the first Portuguese colonial town was established in Sao Vincente, and in 1549 a colonial capital was established Salvador on the Bahiha de Todosos Santos, which signalled the intent of Portugal to settle and protect the region from other rival European powers. ${ }^{47}$ This move to colonise Brazil was to benefit Portugal, as in the $16^{\text {th }}$ Century, its fortunes in Asia faced challenges from the Dutch East India Company. In the centuries to follow Brazil witnessed numerous struggles and uprisings between the natives ${ }^{48}$ and later amongst the settlers ${ }^{49}$ of the land to seize power.

In 1808 the Portuguese Royal Court relocated to Brazil, as a tactical move to evade Napoleon's army which had invaded and captured Iberia, and in 1815 Brazil was elevated to

41 Sundaram (n 22).

${ }^{42}$ Sundaram (n 22).

${ }^{43}$ The present day Federative Republic of Brazil (Brazil) covers an area of 3,286,488 square miles, and is the largest country in South America. It shares a border with almost all the countries in the continent, except Chile and Ecuador, and is also the most populous nation in the continent.

${ }^{44}$ A fleet of 13 Portuguese ships under the command of Pedro Álvares Cabral reached Brazil on 23 April 1500. Following in the successful footsteps of Vasco Da Gama's epic voyage to India in 1497, the fleet in 1500 was also headed for India, but the lead ship under the command of Cabral veered off course into the Atlantic, sailing due west, and eventually arrived in Brazil. TE Skidmore, Brazil: Five Centuries of Change (Oxford, 1999) 5; C de Abreu, Chapters of Brazil's Colonial History 1500-1800 (Oxford, 1998) 58-59.

${ }^{45}$ For a brief period of time in the $17^{\text {th }}$ Century, between 1630 and 1654 , the northern part of Brazil (referred to as New Holland) came under Dutch rule through the Dutch East India Company (Vereenigde Oost-Indische Compagnie).

${ }^{46}$ Pope Alexander VI issued a series of papal bulls dividing up the New World between Spain and Portugal. The Spanish kingdom of Castile was granted dominion over all the lands "to the west and south of the so-called Azore and Cape Verde Island". Portugal was given rights over newly explored (and non-Christian) areas of Africa and Asia. Following protests by Portugal an agreement was signed on 14 June 1494, called the Treaty of Tordesillas. The treaty drew the demarcation line between the current marking of 48 and 49 degrees west of Greenwich, which effectively gave Portugal the control of a piece of west coast of Brazil. TA Meade, A Brief History of Brazil (Infobase Publishing, $2^{\text {nd }}$ edn 2010) 12.

${ }^{47}$ Meade (n 46) 43.

${ }^{48}$ Karl Friedrich Philipp von Martius, a German naturalist who travelled and wrote about Brazil in the $19^{\text {th }}$ Century was of the view the real history of Brazil was the mixing of its human elements, namely, native Indian tribes, Europeans, and the Africans. He famously quoted that, "The history of Brazil will always be primarily a branch of Portuguese history. However, if Brazilian history is to be complete and to deserve the name history, it can never exclude the roles played by the Ethiopian and Indian races." S Schwartz, 'Introduction' in C de Abreu, Chapters of Brazil's Colonial History 1500-1800 (Oxford, 1998) xviii.

${ }^{49}$ More than half of Brazilians claim European ancestry through immigrants from Portugal, Germany, Italy, Spain and other countries. Nearly 44 percent claim ancestry from African slaves imported by the Portuguese settlers. The other ethnicities come from Middle East and Asia, which also includes the largest settlement of Japanese outside Japan. Interestingly, less than a 1 percent of the total population can be traced as descendants of the indigenous people who inhabited the land before the arrival of the European settlers in 1500. Meade (n 46) xvi. See also Skidmore (n 44) at 42, where the author mentions the role of Britain in the abolition of slavery in Brazil. 
the status of an empire. ${ }^{50}$ On 22 September 1822, Prince Pedro I declared himself as 'Emperor Pedro I' of Brazil, and the following year in September 1823 Brazil proclaimed independence from Portugal. ${ }^{51}$ The newly independent state of Brazil adopted its first constitution in $1824^{52}$ and was in the same year recognised by the United States (US) and then by Britain in $1825 .{ }^{53}$ Despite these developments, Emperor Pedro I was to return to Portugal in 1831, to attend to political matters in Portugal, leaving Pedro II to be the ruler of Brazil, in his absence. This saw the beginning of a period of revolt, struggle and a five year warfare with Paraguay which eventually ended with the brutal defeat of Paraguay in 1871, and leaving Brazil with a huge fiscal deficit. ${ }^{54}$ Brazil was to pass laws in 1888 abolishing slavery after years of struggle and international pressure from the US, Britain, ${ }^{55}$ and France. ${ }^{56}$ On 15 November 1889, the emperor Dom Pedro II was ousted from power in a bloodless coup and went into exile in Portugal. This effectively brought to an end monarchic rule in Brazil and also Portugal's direct intervention in Brazil's governance. Following the ouster of Dom Pedro II, Brazil's second constitution was written in 1891, paving the way for the creation of a federation, with extensive powers granted to regional governors.

\subsection{Brazilian Constitution}

It is necessary for our purposes to trace the roots of the modern day Brazilian constitution from the time Brazil declared itself a Republic, as it presents an interesting picture of the crucial role the nation's constitution played in recognising the right to health as a constitutional right, in the formulation of health policies in its fight against AIDS/HIV, and also in the implementation of TRIPS flexibilities in the late 1990's. The 1891 Constitution, the first constitution of the Republic, replaced monarchy with a directly elected president. ${ }^{57}$ Although a Civil law country, Brazil's Constitution was drawn up along the lines

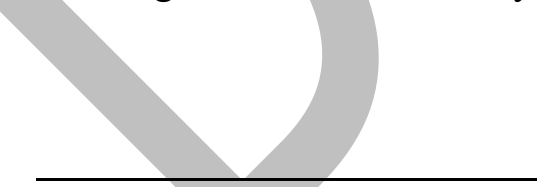

${ }^{50}$ Dom João VI had set sail to Brazil in November 1807 with about ten thousand courtiers in forty six ships and accompanied by four Royal Navy vessels. Skidmore (n 44) 37; PV Shaw, 'Jose Bonifacio and Brazilian History,' The Hispanic American Historical Review, Vol 8, No 4 (1928) 527, 529. The United Kingdom of Portugal, Brazil and Algarve was formed in 1815 following the transfer of the Portuguese court to Brazil and lasting till 1822.

${ }^{51}$ Emperor Pedro I was the son of Dom João VI of Portugal. It is to be noted that no other former colony has ever embraced as its monarch a member of the ruling family of the very country it rebelled against to attain freedom. Skidmore (n 44) 37. Emperor Pedro I had the backing of the Brazilian Aristocracy, and the British, who were eager to monopolize the trade links with Brazil. Meade (n 46) 69.

52 The 1824 Constitution, also known as Constituição Política do Império do Brasil, governed the country for six decades after Independence (1822-1889). Following the adoption of its first Constitution, Brazil enacted its first Criminal Code in 1830 followed by the Commercial Code in 1850, and interestingly no Civil Code was enacted during this period.

${ }^{53}$ Recognition by Britain was more crucial, as it was the leading European power in the $19^{\text {th }}$ Century. Besides, Brazil owed Portugal a debt of $\$ 7,000,000$, which in turn Portugal had borrowed from Britain. During this period Britain was a dominant player in Brazilian economy through trade and direct investment. Skidmore (n 44) 42; Meade (n 46) 70.

${ }^{54}$ Brazil was also constrained to take very big loans from Britain to finance the war. Skidmore (n 44) 62-64.

${ }^{55}$ British warships entered the Brazilian territorial waters in 1850 , with a view to seize and destroy ships carrying contraband slaves. Meade (n 46) 79.

56 The abolitionist arguments were starting to be heard during the late 1860s and early 1870 s and gradually took a firm grip on the society. On 13 May 1888, after several failed attempts in Parliament and nearly 18 years from the day the war with Paraguay was won, the Brazilian Parliament passed legislation approving total and immediate abolition of slavery without compensation to the former slave owners. Skidmore (n 44) 65-70.

57 The 1891 constitution also disestablished the Roman Catholic Church, and the new government also ordered the destruction of all records relating to slavery. The objective was twofold, on the one hand it helped destroy the traces of a shameful passage in the history of Brazil, and on the other hand it also made it impossible for any attempts from the former slaveholders for compensation. Skidmore (n 44) 75-76. 
of the US Constitution, ${ }^{58}$ except for certain parts derived from the Argentine Constitution of 1853-60. ${ }^{59}$ The 1891 Constitution was to remain in force till 1934, when the members of the Brazilian Constituent Assembly signed a new Constitution on 16 July 1934. The Constitution signed in 1934 had a very short life span, as it was to last a mere three years before being replaced by the 1937 Constitution. ${ }^{60}$

\subsubsection{Declaration of Rights: 1891 to 1988}

Interestingly, the 1891 constitution contained a Declaration of Rights, drawing largely from the First Amendment of the US Constitution, ${ }^{61}$ and was liberal and secular. A large part of the individual rights contained in the 1891 Constitution were retained in the Constitution of 1934, with a further declaration that Brazil will not resort to a War of Conquest. ${ }^{62}$ The 1937 Constitution while retaining most of the rights contained in the 1934 Constitution, reintroduced capital punishment for certain offences. The Constitution of 1946 increased the rights ${ }^{63}$ and contained more guarantees for the citizens. Further, it also abolished capital punishment which was reintroduced under the 1937 Constitution. Brazil was to go through a phase of tumultuous change through military dictatorship in the 1960 's, ${ }^{64}$ which was to last for over two decades and saw the Constitution and the Declaration of Rights therein contained suspended for a similar period of time. This marked a low point in the modern history of Brazil and took the nation decades to recover from, as it caused much harm to its socio-economic conditions and left the political institutions, if not defunct, in disarray. By the time the military lost power in 1985 the inflation was at an all-time-high of 235 percent. ${ }^{65}$

Rebuilding of parliamentary democracy after a hiatus of over two decades required the new government to work on the creation of a new Constitution to replace the 'Institutional Acts' passed by the military rule, ${ }^{66}$ and thereby restore faith in democracy. The task was entrusted to the Constituent Assembly which was elected in 1986, to act as the Constitutional Convention. The drafting process witnessed lengthy debates and intense lobbying, both in the

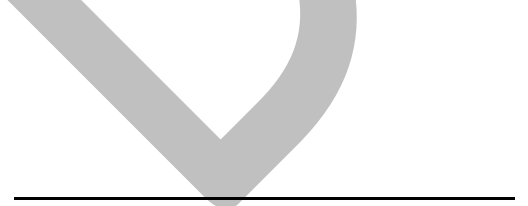

${ }^{58}$ Unlike Brazil, which has a Civil law legal system, the US legal system is based on the Common law legal traditions derived from Britain. While Britain has an unwritten constitution, the US has an elaborate written Constitution.

${ }^{59}$ M Wayler, 'The Development of the Brazilian Constitution: 1891-1946' Journal of Comparative Legislation and International Law, Third Series, Vol. 31, No.3/4 (1949) 53-60, 53. The author also points out that the Argentine Constitution as well was based on the US Constitution.

${ }^{60}$ Ibid.

${ }^{61}$ The US Constitution is credited with having a detailed Bill of Rights in the form of amendments, guaranteeing a number of personal freedoms for its citizens.

${ }^{62}$ Articles 4 and $113 \mathrm{Nr} 9$ of the Brazilian Constitution 1934. M Wayler(n 59) 58.

${ }^{63}$ Contained in Chapter II Title IV (of Individual Rights and Guarantees). M Wayler (n 59) 58.

${ }^{64}$ On 31 March 1964, the military forces seized key government offices in Brasilia and Rio, and power was seized by the military in a near blood-less coup. The then US president Lyndon Johnson recognised the military government within hours of the coup. As the military government had no legitimacy under the 1946 Constitution, the military high command swiftly issued a legitimizing decree on 9 April 1964, called an 'Institutional Act.' This self-proclaimed law gave the military the power to do almost anything it wished. Skidmore (n 44) 155-162.

${ }^{65}$ W Baer, The Brazilian Economy, 4th ed. (Westport, 1995) 392-93. See also Skidmore (n 44) 178.

${ }^{66}$ Brazil's transition from a dictatorship to a democracy took a painful and arduous ten years, starting in 1974 with the gradual liberalization of the military regime when General Ernesto Geisel assumed power. Although the military rule came to an end in 1985, the first civilian president in over a decade, Tancredo Neves, died before assuming office. This led to the Vice President, Jose Sarney being sworn in as Brazil's transitional president. S Mainwaring, 'The Transition to Democracy in Brazil,' Kellogg Institute Working Paper No 66 (March 1986) 8$13<$ https://kellogg.nd.edu/publications/workingpapers/WPS/066.pdf> (accessed 28 March 2014). See also Skidmore (n 44) 184-192. 
parliament and in public, and took over a year to complete. ${ }^{67}$ The Republic's seventh ${ }^{68}$ Constitution was successfully passed on 5 October 1988, enshrining provisions that conferred extraordinary rights on citizens, which were not identifiable in the previous editions of the Constitution. One feature that stood out was the recognition of right to health as a constitutional right. The 1988 Constitution ${ }^{69}$ guarantees access to health services, which also includes access to basic medicines. An English translation of Article 196 reads as follows:

Health is a right of all and the responsibility of the State, to be guaranteed by means of social and economic policies aimed at reducing the risk of illness and other hazards, and all the universal and equal access to actions and services for its promotion, protection and recovery.

Most importantly, under the 1988 Constitution, ${ }^{70}$ right to health is not an aspiration but a fundamental right, which creates rights in citizens and obligations in the State, professing instant application. Drawing from the Civil law traditions, the Constitution grants the above private rights on the citizens. ${ }^{71}$ Article $6^{72}$ declares that education, health, work, leisure, security, social security, protection of maternity and infancy, and assistance of the unprotected are social rights. Under the 1988 Constitution the right to health is viewed as an essential condition in preserving the constitutional principles of the dignity of the human person guaranteed in Article 1, III, ${ }^{73}$ and the right to life guaranteed under Article 5. ${ }^{74}$

\subsection{Brazilian National Health System: Sistema Único de Saúde (SUS)}

Brazil's contribution in the area of access to health and medicine is widely recognised, as it has a well-developed national health system, ${ }^{75}$ strongly predicated on the right to health

${ }^{67}$ Skidmore (n 44) 190-192. Some 61,142 amendments were proposed and 21,000 speeches were delivered before the finalisation of the draft. The final draft was a lengthy, detailed and convoluted document, containing 245 articles and 70 transitory provisions. See KS Rosenn, 'Brazil's New Constitution: An Exercise in Transient Constitutionalism for a Transitional Society’ Am J Comp L. Vol. 38, No. 4 (Autumn 1990) 773-802, 777.

${ }^{68}$ Rosenn (n 67) 773. The author expresses the view that it could be seen as the eighth constitution, if a constitutional amendment that redrafted the entire constitution was to count as a new constitution.

${ }^{69}$ Article 196 of the 1988 Brazilian Constitution.

${ }^{70}$ Article 5, para. 1: "Rules defining fundamental rights and guarantees have instantly binding application." See VA da Silva, "Taking From the Poor to Give to the Rich: The Individualistic Enforcement of Social Rights" Presented as workshop paper at the "VII World Congress of the International Association of Constitutional Law, Athens, $\quad$ Greece (14 June 2007) $<$ http://www.enelsyn.gr/papers/w13/Paper\%20by\%20Prof.\%20Virgilio\%20Afonso\%20da\%20Silva.pdf> (accessed 28 March 2014).

${ }^{71}$ It is clear from a reading of Articles 1 and 2 that, besides its main goal of legitimizing democracy, preserving sovereignty, citizenship, and the dignity of human beings, the 1988 Constitution also aimed at achieving new goals in the form of improving the social conditions of the nation as a whole. M Piancastelli, 'The Federal Republic of Brazil' in A Global Dialogue on Federalism, vol 2: Distribution of Powers and Responsibility in Federal Countries, ed. Akhtar Majeed, Ronald L Watts, and Douglas M Brown (Montreal and Kingston: McGill-Queen's University Press for the Forum of Federations 2006) 66-90, 69.

${ }^{72}$ Article 6 (Title II, "Fundamental Rights and Guarantees," chapter II, “Social Rights"): "Education, health, work, leisure, security, social security, protection of motherhood and childhood, and assistance to the destitute, are social rights, as set forth by this Constitution."

${ }^{73}$ Article 1: The Federative Republic of Brazil, formed by the indissoluble union of the states and municipalities and of the Federal District, is a legal democratic state and is founded on: I. sovereignty; II. citizenship; III. the dignity of the human person; IV. the social values of labour and of free enterprise; V. political pluralism.

74 Article 5: All persons are equal before the law, without any distinction whatsoever, Brazilians and foreigners residing in the country being ensured of inviolability of the right to life, to liberty, to equality, to security and to property, on the following terms: (I - LXVII).

${ }^{75}$ MSG Rosina, DWL Wang, and TC de Campos, 'Access to Medicines: Pharmaceutical Patents and the Right to Health,' in L Shaver, Access to Knowledge in Brazil: New Research on Intellectual Property, Innovation and Development (2010) 103. 
guaranteed under its Constitution. Brazil established the National Health System, or Sistema Unico de Saúde (SUS), ${ }^{76}$ to implement the constitutional right to health. Though the 1988 Constitution does not identify access to medicines as a constitutional right, the legislation implementing the right to health does so. ${ }^{77}$ Article 6(I) of Lei 8.080/90, specifically addresses this issue, by stating that SUS

...must be responsible for promoting full medical assistance, which includes pharmaceutical assistance.

The setting up of the SUS enabled to bring in some 60 million people who were excluded from the earlier centralised National Health Service operated under the military rule. ${ }^{78}$ The SUS treats those who seek access to health services as rights-holding citizens rather than 'empowered clients,' which is a clear departure from the earlier system where the seekers/patients were seen as passive recipients. ${ }^{79}$ The SUS has been built on the principles of universality, comprehensive care, equity, decentralisation and social oversight (controle social).$^{80}$ In short, the SUS is a publicly-funded rights-based universal health system, which does not restrict access to medical care and medicines to its citizens, but one that empowers them to seek access to healthcare and medicines. The pursuit of access to health started with the decentralisation of the health system. Further health care laws were passed in 1990, 1993, and 1996 to define more clearly the role of each level of government in delivering healthcare as envisaged under the Constitution. ${ }^{81}$ The SUS, in its 25 years of operations, has fundamentally transformed the Brazilian health care system to achieve its Constitutional guarantee of right to health.

\subsubsection{Response to HIV/AIDS Epidemic: Right to Health \& Pharmaceutical Patents}

A study of Brazil's TRIPS Agreement implementations cannot be carried out without paying due attention to its 'right to health agenda' and the fight against HIV/AIDS. Brazil launched its anti-AIDS programme in 1983, and its response to HIV/AIDS in the years to come was very positive and to be lauded, especially coming soon after emerging from over two decades of military rule. The 1988 constitution, which heralded a new era by conferring the right to health as a constitutional right, and the pioneering work of Brazilian researchers, under the leadership of Bernardo Galvão-Castro, in the isolation of the HIV virus in the 1980's can be viewed as contributing factors in the robust response of Brazil to the HIV/AIDS epidemic. Two years prior to the promulgation of the new Constitution, Brazil, in response to the epidemic, established its National STD and AIDS Committee (CNAIDS), a national AIDS Committee, and also a National AIDS/STD Control Programme (NAP). ${ }^{82}$ The Brazilian government developed an aggressive and innovative programme with a strong emphasis on

\footnotetext{
${ }^{76}$ Brazil passed Lei 8.080/90 known as the Health Act (Lei Orgânica da Saúde) and Lei 8.142/90 to establish the SUS. This public health system was to deliver a guaranteed universal health care to all Brazilian citizens.

${ }^{77}$ Rosina, et al (n 75) 105.

${ }^{78}$ Rosina, et al (n 75) 105.

${ }^{79}$ A Cornwall and A Shankland, 'Engaging Citizens: Lessons from Building Brazil's National Health System,' Social Science \& Medicine 66 (2008) 2173-2184, 2174. The authors argue that the impetus for the SUS grew out of the successful mobilisation by the Movimento pela Reforma Sanitária (movement for health reform) which gathered momentum in the 1980's, and the innovative institutional experiments in the post-dictatorship period.

${ }^{80} \mathrm{Ibid}, 2175$. See also M Gragnolati, M Lindelow, and B Couttolenc, Twenty Years of Health System Reform in Brazil: An Assessment of the Sistema Único de Saúde (The World Bank 2013) 17, 25.

${ }^{81}$ A Nunn, The Politics and History of AIDS Treatment in Brazil (Springer 2009) 18.

${ }^{82}$ Nunn (n 81) 23.
} 
both prevention ${ }^{83}$ and treatment through early government response, effective participation of civil society, and the advocacy of human rights in all strategies and actions. In May 2005, Brazil courted controversy, when it turned down over US\$40 million worth of aid money from the US, as acceptance of the money would require Brazil to condemn commercial sex workers, advocate sexual abstinence, which would thereby have the effect altering its anti-AIDS programme. ${ }^{84}$ These measures alone were not sufficient for health care for the individuals, as any policy drafted in this regard was strongly reliant on the right to health guaranteed under the 1988 Constitution. Unfortunately the decentralised public health institutions could only become operational after the Brazilian Congress passed the Basic Orientation Laws (Normas Operacionais Básicas) in the 1990's. ${ }^{85}$

According to a World Bank projection, made in the early 1980 s, Brazil was expected to have 1.2 million people living with HIV by 2000, but statistics from 2006, on HIV prevalence showed that only an estimated 660,000 Brazilians lived with HIV/AIDS, which was purely down to Brazil's extensive HIV/AIDS Programme. ${ }^{86}$ Even then, Brazil had the highest absolute number of HIV cases than any other country in Latin America ${ }^{87}$ The National Program for Exceptional Medicines which was established under Ordinance 2.577/06, supplied strategic medicines for the treatment of HIV/AIDS, malaria, tuberculosis, influenza and meningitis. ${ }^{88}$ Brazil also passed Lei $9.313 / 96$ to guarantee free and universal access to all HIV/AIDS treatments within the SUS, thereby setting up a publically funded health care system to provide free universal access to highly active antiretroviral therapy (HAART) for people living with HIV/AIDS (PLWHA) ${ }^{89}$ It is the first developing country to implement a large-scale universal ARV distribution program. Brazil in the mid-1990s decided to take direct action in its fight against HIV/AIDS and began producing seven non-patented antiretroviral drugs (ARVs) in the Health Ministry factories and laboratories, ${ }^{90}$ which only produced limited results due the new patent laws introduced in $1996 .{ }^{91}$ The new laws which were introduced pursuant to the TRIPS Agreement, required Brazil to recognize intellectual property rights

${ }^{83}$ Brazil's anti-AIDS policy specifically targeted high-risk groups with safe sex advocacy, including the distribution of condoms to sex workers. URQ Marques, VS Guimarães, and C Sternberg, 'Brazil's AIDS Controversy: Antiretroviral Drugs, Breaking Patents, and Compulsory Licensing’ Food \& Drug LJ Vol. 60 (2005) 471-477.

${ }^{84}$ Marques et al (n 83) 473. The funding was provided under the US Global AIDS Bill, which has come under sever international criticism as it requires that one-third of all AIDS funding must go to groups that promote sexual abstinence only. See also, 'Brazil Refuses \$40M in US AIDS Grants To Protest Policy Requiring Groups To Condemn Commercial Sex Work,' Kaiser Health News, Daily Reports (2 May 2005) $<$ http://www.kaiserhealthnews.org/Daily-Reports/2005/May/02/dr00029729.aspx?p=1> accessed 15 April 2014. Pedro Chequer, the Director of Brazil's AIDS programme and chair of the National Commission that decided to refuse the grant of over US\$40 million in US aid money was quoted as saying that it viewed the Bush administration's policy as 'interference that harms the Brazilian policy regarding diversity, ethical principles and human rights.'

${ }^{85}$ Nunn (n 81) 18.

${ }^{86}$ URQ Marques, VS Guimarães and C Sternberg, 'Brazil's AIDS Controversy: ARV Drugs, Breaking Patents, and Compulsory Licensing’ Food \& Drug LJ 60 (2005) 471-477, 471.

${ }^{87}$ Nunn (n 81) 21.

${ }^{88}$ Rosina, et al (n 77) 106.

${ }^{89}$ Nunn (n 81) 24; F Orsi, L Hasenclever, B Fialho, P Tigre, and B Coriat, 'Intellectual Property Rights, AntiAIDS Policy and Generic Drugs: Lessons from Brazil' in J-P Moatti, B Coriat, Y Souteyrand, T Barnett, J Dumoulin, and Y-A Flori, Economics of AIDS and Access to HIV/AIDS Care in Developing Countries, Issues and Challenges, (ANRS, Paris 2003) 110-135, 112.

${ }^{90}$ Lie 5772/71 created the legal right for local firms to produce on-patent drugs, and as a result a number of private firms in the 1970's were able to take advantage of the law and legally reverse-engineer on-patent pharmaceuticals. See JC Cohen and KM Lybecker, 'AIDS Policy and Pharmaceutical Patents: Brazil's Strategy to Safeguard Public Health’ The World Economy, Vol. 28, Issue 2 (2005) 211-230, 214-215.

${ }^{91}$ Nunn (n 81) 25. Brazil's domestic pharmaceutical industry is a major supplier to the domestic public health system, historically benefitting from decades of a regime of non-patent protection. See Cohen (n 90) 214. 
protection for pharmaceutical products for 20 years, and did not allow for the realisation of the goals set under the NAP. The success and failure of the health care system and the response to HIV/AIDS epidemic cannot be judged without a study of some of the internal and external factors which had come to interfere in the realisation of the constitutional goal of right to health. The implementation of the TRIPS Agreement into Brazil's national laws, and the use of flexibilities afforded under the said Agreement are identified as key factors that have further influenced, or rather hindered in the delivery of the health care system through the SUS, and the same are studied in the following sections.

\subsection{Brazilian Patent Laws: The $19^{\text {th }}$ Century Alvará to TRIPS Implementation}

Brazilian patent law dates back to 1809 when a system of licensing, or, alvará, ${ }^{92}$ was introduced by Dom João VI, to stimulate invention in an economy primarily driven by agriculture. Brazil's first Constitution of 1824 recognized the right of inventors to a privilege, or remuneration for the use of their invention, which was followed by the passing of the 1830 laws recognizing the rights of inventors. ${ }^{93}$ Brazil introduced new patent laws in 1882, nearly 60 years after independence from Portugal. The new laws were based on universal novelty, and granted for a period of 15 years, with the state retaining the right to appropriate the patent on grounds of public necessity or utility. ${ }^{94}$ The laws introduced in 1882 even contemplated the possible grant of patents on chemicals and pharmaceuticals, and proceeded to set up a system of targeted examination of select areas of patents which affected public interests, namely, food, chemicals and pharmaceuticals. ${ }^{95}$ It is worth mentioning that Brazil is one of the founding members of the Paris Convention ${ }^{96}$ and Berne Convention, ${ }^{97}$ which were concluded round about the time its new patent laws were introduced in 1882. It is safe to assume that the laws enacted in 1882 did not in any way contribute to the economic growth of the nation in the nineteenth century, and had minimal impact. ${ }^{98}$ Brazil adopted a policy of Import Substituting Industrialisation (ISI) ${ }^{99}$ in the 1950's and 1960's which required regulation of the transfer of technology mechanism from foreign to domestic companies on terms more suitable for its own goals. ${ }^{100}$

92 Dom João VI set up the first license system alvará for inventions of new machines, following which one of the first patents was granted to a mining service machine in 1814. RA Brandos, 'Brazilian Patent System: A Brief Introduction,' INPI (National Institute of Industrial Property), Brazil (2012).

${ }^{93} \mathrm{P}$ Drahos, The Global Governance of Knowledge: Patent Offices and Their Clients (Cambridge 2010), 242243.

${ }^{94}$ Ibid 243. Article I, Section 4 vested the government to appropriate the patent on grounds of public necessity or utility.

95 Ibid 244.

96 The Paris Convention for the Protection of Industrial Property 1883.

${ }^{97}$ The Berne Convention for the Protection of Literary and Artistic Works 1886.

${ }^{98}$ Drahos (n.93) 244. The author is of the view that the little economic growth that Brazil witnessed during the above period was through agricultural exports and textiles, but this export growth did not stimulate high levels of technological progress.

${ }^{99} \mathrm{C}$ Schulz and M Wu, 'The TRIPS Agreement and Intellectual Property Protection in Brazil,' Proceedings of the Annual Meeting (American Society of International Law), Vol.98 31, March-3 April (2004) 100-106, 100. During this period there was limited patent protection for pharmaceutical/chemical products and processes, along with an explicit government policy of import substitution of industrialized products, which led to the expansion of important sectors like, automobile, petrochemicals, steel, etc., as well as the implementation of large infrastructure projects leading to economic growth.

${ }^{100}$ Drahos (n.93) 245. See also W Baer, 'Import Substitution and Industrialization in Latin America: Experiences and Interpretations,' Latin American Research Review, Vol. 7, No.1 (Springer, 1972) 95-122, 101-102. The author expresses the view that the Brazilian government through ISI was anxious to promote maximum vertical integration, i.e., to promote both final consumer goods industries and intermediate and capital goods sectors. Despite the promotion of ISI, over 90 per cent of Brazil's exports still continued to be from the traditional sectors of food product in the late 1960's. 
While implementing the ISI policy, Brazil undertook a review of its patent laws, as under existing norms overseas patent holders of technology were more advantaged as they could easily exploit the laws to create monopoly, and also negotiate a better price for the use of their technology. ${ }^{101}$ In response, Brazil reformed its patent laws to have better control over the technology transfer process. ${ }^{102}$ As part of the reformative measure, the National Institute of Industrial Property (NIIP), or InstitutoNacional da Propriedade Industrialwas formed, and was also entrusted with the key responsibility of administering patent law and technology transfer agreements. ${ }^{103}$ In December 1971, Brazil made further revision to its patent laws in Lei No. 5.772/71, excluding a number of pharmaceutical processes and products from the grant of patent. Under the 1971 laws the term of patent was to last for 15 years, and also contained provision for pre-grant opposition from third parties. Most notably, the 1971 laws contained provisions for the grant of compulsory licenses, including on the grounds of an absence of actual working of the patent in Brazil. ${ }^{104}$

In 1991, new intellectual property legislation was presented to the Congress by the then President Collor de Mello for discussion, with a view to bring Brazil's laws into compliance with the TRIPS Agreement. ${ }^{105}$ While the bill was still being debated, the Congress approved the TRIPS Agreement in Legislative Decree No. 1,355 of December 30, 1994, which became effective in Brazil on January 1, 1995. ${ }^{106}$ Although TRIPS Agreement's transitional provisions under Article 65 permits the delayed implementation ${ }^{107}$ of the product patent regime for pharmaceutical patents in developing countries, Brazil failed to take advantage and delay the implementation. ${ }^{108}$ As a result, the TRIPS Agreement was incorporated in its entirety into Brazil's legal system in 1997 bringing about a series of problems in its wake. Also, the Brazilian Patent and Trademark Office (INPI) was convinced that Brazil was not required to expressly state that it would make use of these provisions. ${ }^{109}$ Notwithstanding the position taken by the INPI on the application of TRIPS Agreement to its national laws, patent owners started lodging applications for grant of pharmaceutical and chemical patents immediately after 1 January 1995, under Article 70(8) of the TRIPS Agreement. ${ }^{110}$

In 1996 the Brazilian Congress under President Cardoso passed the Industrial Property Law (LPI) Lei 9.279/96 to repeal the 1971 patent law, and the new laws came into force on 15 May 1997. Under the old laws (Lei 5.772/71 Art 9c.), patenting of pharmaceuticals process

\footnotetext{
${ }^{101}$ Drahos (n 93) 246.

102 Drahos (n 93) 246-247.

${ }^{103}$ In December 1970 Brazil passed Lei 5.648 establishing the National Institute of Industrial Property (NIIP) or (Instituto Nacional da Propriedade Industrial).

${ }^{104}$ Drahos (n 93) 248.

105 Schulz and $\mathrm{Wu}$ (n 99).

106 Schulz and $\mathrm{Wu}$ (n 99).

107 The key flexibilities built into the TRIPS Agreement are, compulsory licensing under Article 31, experimental use under Article 30, parallel imports under Article 6, Bolar exceptions under Article 30, and health sector participation in analysing pharmaceutical patent claims which is implied under Article 8. Besides the above flexibilities, the TRIPS Agreement, under Articles 65(2) and 65(4), in certain cases, allow delaying the application of the provisions on product patents to such areas of technology for an additional period of five years. See also L Chung, 'Use of Paragraph 6 System for Access to Medicines' (2010) 36 NCJ Int'1 L \& Com Reg 137, 174. See also SF Musungu and $\mathrm{C}$ Oh, The Use of Flexibilities in TRIPS by Developing Countries: Can They Promote Access to Medicines (South Centre, 2006) 8-9. The authors discuss in detail time-bound and other flexibilities available to the developing countries and the LDCs in the implementation of the TRIPS Agreement.

108 The use of Part 4 of Article 65 of the TRIPS Agreement could have enabled Brazil to extend the transitional period for yet another five years. See Schulz and Wu (n 99). See also Sundaram (22). India, another developing country and a generics manufacturer, delayed the implementation of the product patent regime for pharmaceutical patents to gain full advantage of the transitional arrangements under Article 65 of the TRIPS Agreement.

${ }_{109}$ Schulz and $\mathrm{Wu}$ (n 99).

${ }^{110}$ Schulz and $\mathrm{Wu}$ (n 99). The INPI ignored these applications until a 2001 law determined that all chemical and pharmaceutical product patents should be regularly examined.
} 
and products was forbidden. The new law of 1996 introduced a higher level of protection for pharmaceutical patents, and also allowed for the patenting of chemical products. Brazil's early compliance to the TRIPS Agreement proved to be a grave mistake, as it witnessed the price of ARVs rise due to the elimination of the possibility of generic production of patented drugs domestically. Some writers attribute the early changes brought about to the Brazilian legislation down to economic and political pressure exerted by US to comply with the TRIPS Agreement before the 2005 legal deadline, ${ }^{111}$ while others attribute it to pressure from multinational pharmaceutical corporations seeking to exploit newer foreign markets through a higher level of patent protection. ${ }^{112}$ This early compliance was also to greatly disadvantage the implementation of the HIV/AIDS programme envisaged by the Brazilian government.

\subsubsection{Key Provisions 1: Parallel Imports, Bolar Exception \& Compulsory Licensing}

The global discussion on the issue of compulsory license became more intense in the early 1990s in the wake of the HIV/AIDS crisis. The discussions presented a grim picture of the situation prevailing in the developing countries and LDCs, where the most affected populations came from, and access to ARV treatment was not possible due to exorbitant costs. In the above regions, patented drugs for the treatment of the disease are unaffordable and beyond the reach of the sufferers, and generic ARVs were, and still are, seen as the only affordable option, and solution, for the frontline treatment HIV/AIDS sufferers. ${ }^{113}$ It is worth mentioning that patent protection is often cited as the key contributing factor for the nonaffordability of medication for the treatment of HIV/AIDS. ${ }^{114}$ In such instances the grant of compulsory licenses or, the threat of such a grant by the concerned government is the only option for the procurement of generic ARVs. One of the main reasons for the failure in the attempts to revise the Paris Convention 1983 in the late 1980's and early 1990's is attributed to the developed and developing countries disagreeing on the extent of powers that governments should retain for the grant of compulsory licenses, and the how those powers if and when retained are to be exercised. ${ }^{115}$ Compulsory licensing of patented drugs, which enables the access to essential medicines in times of need, is identified as one of the essential pillars of the patent system and is recognised under the TRIPS Agreement and also under other international conventions. ${ }^{116}$ The Doha Declaration unequivocally states that every WTO

\footnotetext{
111 Orsi, et al (n 89) 113.

112 Rosina, et al (n 75) 115.

113 Sundaram (n 22) 13.

${ }^{114}$ B Waning, E Diedrichsen and S Moon, 'A Lifeline to Treatment: The Role of Indian Generic Manufacturers in Supplying Antiretroviral Medicines to Developing Countries' (2010) Journal of International AIDS Society $<$ http://www.biomedcentral.com/content/pdf/1758-2652-13-35.pdf $>$ accessed 28 March 2014.

115 JH Reichman, 'Compulsory Licensing of Patented Pharmaceutical Inventions: Evaluating the Options' in CM Correa (ed), Research Handbook on the Protection of Intellectual Property under WTO Rules: Intellectual Property in the WTO, Vol. I (Edward Elgar, 2010) 589-622; JH Reichman and C Hasenzahl, 'Non- Voluntary Licensing of Patented Inventions: Historical Perspective, Legal Framework under TRIPS, and an Overview of the Practice in Canada and the USA', UNCTAD and ICTSD Project on IPRs and Sustainable Development, Issue Paper No. 5 (June 2033) <http://ictsd.org/i/publications/11764/> accessed 10 April 2014.

${ }^{116}$ Article 31, TRIPS Agreement ('Other Use Without Authorization of Rights of Holder') and Article 30, TRIPS Agreement ('Exceptions to Rights Conferred'). The Doha Declaration, seen as a corollary to the TRIPS Agreement, proclaims that each member had the right to grant compulsory licenses. The WHO has recommended the use of compulsory licenses where there is "abuse of patent rights or a national emergency" in order to ensure that drug prices are consistent with the purchasing power of the local government. As regards other international conventions go, Article 5A of the Paris Convention for the Protection of Industrial Property provides for the signatories to the Convention to have the right 'to take legislative measures providing for the grant of compulsory licenses to prevent the abuses which might result from the exercise of the exclusive rights conferred by the patent, for example, failure to work.' Under Art 5A 'failure to work,' or 'insufficient working' of a patent would tantamount to abuse of the patent rights, and can be viewed as giving rise to grounds for the grant of compulsory
} 
Member has 'the right to grant compulsory licences and the freedom to determine the grounds upon which such licences are granted.' ${ }^{117}$ Importantly, the text of Article 31 of the TRIPS Agreement was consciously drafted by the negotiating group to avoid any disease-based limitation being imposed on the member countries seeking to invoke the provision. ${ }^{118}$ Canada and the United Kingdom (UK), both developed countries, have used compulsory licensing provisions available under their national legislations whenever possible. ${ }^{19}$ The US has not adopted a statutory regime of granting compulsory license, but has nevertheless allowed the practice under antitrust laws. ${ }^{120}$

One of the most important features of the 1996 LPI was the introduction of provisions relating to the grant of compulsory licenses. The Lei 9.279/1996, passed on 14 May 1996 was to come into force on 15 May 1997, with the exception of 'pipeline' provisions which came into force immediately. The net result was that 'pipeline' applications based on foreign patents for pharmaceuticals and chemical compounds were automatically granted, waiving the novelty requirement. ${ }^{121}$ In 1998, Brazil decided to increase domestic production of generic ARVs and also to issue compulsory licenses on patented ARVs to meet its domestic requirements. In 1999, the Brazilian National Congress set up an Inquest Committee (CPI) to investigate the reasons behind the exorbitant rise in prices of the medicines sold in Brazil. ${ }^{122}$ In 1999 Brazil introduced the National Drug Policy (Health Ministry Portaria 3.916) which was aimed at completely decentralizing drug policy. ${ }^{123}$ A combination of decreasing stocks on ARVs, devaluation of its currency and a pressing need to meet its commitment to the HIV/AIDS

license. GHC Bodenhausen, Guide to the Application of the Paris Convention for the Protection of Industrial Property (WIPO Publication, 2007) 67-73.

${ }^{117}$ Doha Declaration on the TRIPS Agreement and Public Health (n 28).

${ }^{118}$ K Outterson, 'Disease-Based Limitations on Compulsory Licenses Under Article 31 and 31 bis' in CM Correa (ed), Research Handbook on the Protection of Intellectual Property under WTO Rules: Intellectual Property in the WTO, Vol. I (Edward Elgar, 2010) 673-697. The author suggests that the provision has been misunderstood (perhaps deliberately so) in the write-ups in the Wall Street Journal and the Financial Times to imply that Article 31 is only applicable to national public health emergencies like HIV/AIDS or only to the least- developed countries. The pharmaceutical IP system works well in high- income countries with social insurance. It does not work for the poor in low- and middle-income countries.

${ }^{119}$ Canada under its 1923 laws, between 1969 and 1992, issued 613 compulsory licenses for importation and/or local production of medicines as part of its cost containment measures. It changed its laws following its membership of NAFTA (1994) and the WTO (1995), but has continued to issue compulsory licenses. Likewise, the UK had invoked "Crown Use" for the provision of generic medicines for its National Health Service (NHS), which was also unsuccessfully challenged by Pfizer Corporation in the 1960's.

${ }^{120} \mathrm{JH}$ Reichman and C Hasenzahl, 'Non-Voluntary Licensing of Patented Inventions: Historical Perspective, Legal Framework under TRIPS, and an Overview of the Practice in Canada and USA' Issue Paper No. 5, ICTSDUNCTAD Project on IPRs and Sustainable Development (2003) 21; CM Correa, Integrating Public Health Concerns into Patent Legislation in Developing Countries, South Centre, Geneva (2000) 95. The US had in the past granted a number of compulsory licenses to remedy anti-competitive practices and for governmental use, including national security. For instance in the Ciba-Geigy and Sandoz merger of 1997, both pharmaceutical corporations were required to license a large portfolio of patents, haemophilia gene rights, data know-how relating to HSV-tk, etc. to Rhone-Poulenc Rorer. The newly created entity, Novartis, was also required to grant such nonexclusive licenses to requesters in certain instances. In the late 1950s and early 1960s, the US also invoked government use powers on a routine basis to order generic medicines from abroad, regardless of the patent status of the products.

${ }^{121}$ Schulz and $\mathrm{Wu}$ (n 99).

${ }^{122}$ M Basso and EB Rodrigues Jr, Intellectual Property Law in Brazil, (Kluwer, 2010) 78. José Serra, the then State Minister for Health, identified patent protection of pharmaceuticals as one of the most important factor in determining the prices of medicines. Interestingly, one of the recommendations of the CPI was the withdrawal of Brazil's membership of the Paris Convention for the Protection of Industrial Property 1983.

${ }^{123}$ José Serra, the then State Minister for Health, is seen as being key for taking the decision to introduce the National Drug Policy, and also in the increase in production of generic ARVs in Brazil. José Serra, an economist and later a politician, was in exile during the military regime, between 1964 and 1978 in Bolivia, France, Chile, and the United States. 
programme, paved the way for Brazil to pass the 1999 Presidential Decree (under former President Fernando Henrique Cardoso) amending Article 71 of the LPI, relating to the issue of compulsory licenses. ${ }^{124}$ Articles $68-74$, Chapter VIII, Section III of the LPI provide for the grant of compulsory licences if the patent holder exercises the rights therein in an abusive manner or abuses its economic power, or when the patented product is not exploited within Brazil, or when the sale of the patented product fails to satisfy the needs of the market (the "local working" requirement). ${ }^{125}$ Article 68, in particular, requires that the subject matter of the patent must be manufactured in Brazil within three years of receiving a patent, and failure to do so within this time frame will allow Brazilian companies to apply to the government for manufacture of the patented product domestically. ${ }^{126}$ The Brazilian government also passed suitable legislation on Generic Drugs Law in November 1999 to require all government purchasing contracts to be generic drugs ${ }^{127}$ and all prescriptions to be written using generic names. ${ }^{128}$

In 2001, four years after implementing the TRIPS Agreement, Brazil took advantage of the flexibilities and incorporated the Bolar exception, which is contained in Lei 10.196/2001 under item VII to Article 43. Incorporation of the Bolar exception had a twofold advantage for Brazil, as in addition to promoting quicker entry of generic drugs into the market, it also enabled information on the invention to be used for further research into ARVs. ${ }^{129}$ Brazil only has a limited scope for the implementation of parallel import, as its use is restricted to situations where a compulsory license under Article 68, Para 3 and 4 of LPI has been issued due to abuse of economic power by the patent holder. ${ }^{130}$ The issue of parallel imports would fall under the principles of exhaustion of patent rights, ${ }^{131}$ where the rights of a patent holder are exhausted as to those specific goods once it enters the market, and the patent holder cannot prevent their resale to other countries. In this regard the TRIPS Agreement and the Doha Declaration allow member states to determine the scope and extent of exhaustion of patent rights, ${ }^{132}$ although some developed countries remain strongly opposed to this interpretation. ${ }^{133}$ Parallel

${ }^{124}$ Art. 71, Lei 9.279/1996 (enacted May 15, 1997); Nunn (n 81) 112.

${ }^{125}$ Under Article 70 of the LPI, compulsory licenses may also be issued in cases of dependent patents. A compulsory license may be issued under Article 71 by the Federal Executive Authorities in cases of national emergency or public interest. See also CM Correa, 'The Use of Compulsory Licenses in Latin America,' SouthViews No 60 (15 April 2013) <http://alainet.org/active/63292\&lang=es>accessed 16 February 2014. The obligation to work a patent was provided for in a large number of domestic patent laws in the nineteenth century. However, during the twentieth century, most industrialized countries either relaxed or eliminated such an obligation from their laws. This was done primarily to ensure patent holders had the option of exploiting their patents merely through importation and thereby facilitate trans-border activities in an increasingly globalized world market.

${ }^{126}$ Arts. 68-74, Lei 9.279/ 1996 (enacted May 15, 1997); Nunn (n 81) 112.

127 Cohen and Lybecker (n 90) 215.

${ }^{128}$ All prescriptions were to be identified by their generic names, and it was mandated that all packaging carried generic names. Cohen and Lybecker (n 90) 215.

${ }^{129}$ GC Chaves, MF Vieira and R Reis, 'Access to Medicines and Intellectual Property in Brazil: Reflections and Strategies of Civil Society SUR International Journal of Human Rights, Year 5, No 8 (2008) 163-189, 169.

${ }^{130}$ Ibid.

131 The principle of exhaustion is also sometimes referred to as the first sale doctrine.

${ }^{132}$ Article 28(6) of the TRIPS Agreement states that 'This right [i.e., the right of importation], like all other rights conferred under this Agreement in respect of the use, sale, importation or other distribution of goods, is subject to the provisions of Article 6.' In turn, Article 6 of the TRIPS Agreement postulates that 'nothing in this Agreement shall be used to address the issue of the exhaustion of intellectual property rights.' The Doha Declaration in Article 5(d) provides that 'the effect of the provisions of TRIPS Agreement that are relevant to the exhaustion of intellectual property rights is to leave each member free to establish its own regime for such exhaustion without challenge, subject to the MFN and national treatment...'

133 The U.S. delegation to the Council for TRIPS, which met in June 2001, was of the view that Article 6 of the TRIPS Agreement neither allowed WTO members to avail themselves of dispute settlement in relation to questions involving parallel imports, nor authorize parallel imports (Delegation of the United States, Council for 
importation is viewed as an important mechanism for drug access policies, and available under the TRIPS flexibilities for developing countries, that has not been effectively used by Brazil in the implementation process. ${ }^{134}$

Use of Compulsory Licensing Provision: Even though Brazil had never used the obligatory licensing system, it had adopted a strategy of threat to issue compulsory licenses to pressure drug companies in price negotiations for ARV medications. ${ }^{135}$ Since the introduction of the compulsory licensing provisions into Brazilian laws, the US government, as early as January 2001, requested the opening of a consultation with the Dispute Settlement Body (DSU) of the WTO on the above provision, on the basis that the obligation for local production imposed by the Brazilian law violated Articles 27 and 28 of the TRIPS Agreement. As both the US and Brazil reached an agreement the dispute never went before the panel for a full consideration of the issues identified for consultation. ${ }^{136}$ Under the agreement, both the US and Brazil agreed to enter into bilateral discussions before Brazil proceeded to make use of the compulsory licensing provisions under Article 68 against a US patent holder. ${ }^{137}$ This agreement does not, however, prevent Brazil from granting a compulsory license based on article 68, but nevertheless, requires it to enter into bilateral discussions with the US. ${ }^{138}$ The critical factor in making the HIV/AIDS programme and access to medicines being affordable may be the capacity to domestically produce the drugs, and also a credible threat of domestic production used by the Brazilian government. ${ }^{139}$ The strategy had worked well for Brazil as the transnational pharmaceutical companies were willing to lower the price of their products rather than have them produced domestically in Brazil. ${ }^{140}$ It had also seen the reduction in price of some of the ARVs used in the frontline treatment of HIV/AIDS. In 2005, Brazil was able to get the pharmaceutical company and patent holder Abbott Laboratories to lower the price of lopinavir/ritonavir, ${ }^{141}$ which was being actively used in the treatment of about 17,000 patients by 56 per cent. This was achieved through a presidential decree, declaring that the medicine was of public interest and that the patent holder Abbott was required to offer the product at a lower price. Eventually, a deal was struck whereby Abbott Laboratories agreed for a fixed price of US\$1,380 to be charged per patient per year till 2011, regardless of any price variation, in

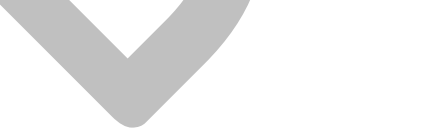

TRIPS Meeting of June 1822, 2001, JOB(01)/97/Add.5, Council for TRIPS, June 28, 2001). See also CM Correa, 'The TRIPS Agreement and Developing Countries' in PJ Macrory and others (eds), The World Trade Organisation: Legal, Economic and Political Analysis Vol. II (Springer 2005) 447.

${ }^{134}$ Chaves, et al (n 129). This is an extremely important mechanism for drug access policies, since multinational pharmaceutical companies usually set different prices for the same drug in different countries. If implemented, Brazil could possibly import medicines from wherever it is sold at the lowest price to benefit its HIV/AIDs programme and also honouring the constitutional right to health.

135 Chaves, et al (n 129) 170-171.

${ }^{136}$ MD Varella, 'WTO, Intellectual Property and AIDS: Case Studies from Brazil and South Africa' (2004) $<$ http://www.marcelodiasvarella.org/marcelodiasvarella/International_Legal_Theory_files/15\%20\%20AIDS-

IPR-WTO.pdf $>$ accessed 28 March 2014.

${ }^{137}$ CM Correa (n 125).

${ }^{138}$ CM Correa (n 125).

${ }^{139}$ Cohen and Lybecker (n 90) 217.

${ }^{140}$ Chaves, et al (n 129) 170-171. The authors also point out that since the Brazilian government had never actually issued a compulsory license (before 2007) for domestic production of any medicines, the negotiating strategy had not been so successful and the prices agreed in later rounds were unsatisfactory. For example, the discounts secured for the new drugs 'tenofovir' and 'atazanavir' (both ARV drugs) were respectively 5.2\% and 7.7\%. Also, the average annual expenditure per patient in 2005 rose to R\$6,124, on a par with the figure in 1998. For a discussion on the role of compulsory licenses as a development strategy, see generally Laura Chung, 'Use of Paragraph 6 System for Access to Medicine' 36 NCJ Int'l L \& Com Reg 137 (2010).

${ }^{141}$ Lopinavir/ritonavir, a fixed dose combination drug which is used in the treatment of HIV infection is marketed by its patent holder Abbott Laborataries as Kaletra and also as Aluvia in different parts of the world. 
return for the Brazilian government guaranteeing that it will not issue any compulsory license for the above drug. ${ }^{142}$

In 2007, for the first time, Brazil went beyond its original strategy of threat to issue a compulsory license. The ARV drug 'efavirenz' marketed as 'stocrinby' by its patent holder Merck Sharp \& Dohme (Merck) was the most used drug in 2007, and the going price that year was US\$ 580 per patient. ${ }^{143}$ Under Brazil's anti-AIDS programme close to 77,000 patients were being treated with efavirenz. During the negotiations, prior to the grant of the compulsory license, Merck was selling efavirenz at a cheaper price in countries of the same development level as Brazil, but with fewer patients in need of treatment than Brazil, and at the same time Indian generic versions of the same drug were much cheaper than Merck's. ${ }^{144}$ Round about the same time the cost of efavirenz in Thailand was approximately US\$ 245 per patient, and the prices for the supply of efavirenz by WHO prequalified laboratories, ranged around US\$ 163 . During negotiations Merck would only offer a price reduction from US\$1.59 to US\$1.10 per dose, and as a result the Brazilian government was constrained to issue a Presidential Decree No 6.108, dated 4 May 2007 granting 'compulsory license, on the ground of public interest, of efaviren's patents, for public non-commercial use' for a period of 5 years, and for a fee of 1.5 percent to the patent owner of the finished product. ${ }^{145}$ Prior to the grant of compulsory license, efavirenz was approximately 12 percent of the cost of the Brazilian Government's expenditures for ARV drugs, and with the loca production of the drug in 2009 the cost dropped to 3.9 percent. ${ }^{146}$ Following the grant of compulsory license, a spokesperson for Merck commented that "this expropriation of intellectual property sends a chilling signal to research-based companies about the attractiveness of undertaking risky research on diseases that affect the developing world." 147 One does not have any doubt that Brazil will continue to explore the use of compulsory licenses if the need arises, as its successful anti-AIDS programme and its commitment to the constitutional right to health and access to medicines strongly hinges on the availability of affordable medicines.

Seizure of Generics Medicines-in-Transit Bound for Brazil: Between 2008 and 2009 , nearly 20 shipments of generic medicines, destined to various developing countries were intercepted and detained by the Dutch and on one occasion by German customs officials, under the purported authority of BMR 1383/2003. ${ }^{148}$ The shipments, which were in transit from India

\footnotetext{
${ }^{142}$ Chaves, et al (n 129) 171. Although the civil society groups in Brazil support the use of compulsory licensing, in the instant case it viewed the deal as imposition of TRIPS-plus provisions, as it included clauses that were more restrictive than those adopted by TRIPS. It is worth mentioning that Brazil used the threat of compulsory licenses on the patent for Glivec (marketed in the USA as Gleevec) to obtain a price discount of more than $65 \%$.

${ }^{143}$ CM Correa (n 125).

${ }^{144} \mathrm{CM}$ Correa (n 125). The author notes that the Indian generic versions were as cheap as US\$0.45 per pill, or an annual cost of US\$164.25 per patient. See also Chaves, et al (n 129) 171, where the authors point out that the drug efavirenz was costing US\$580 per patient since 2003.

145 CM Correa (n 125). Interestingly, Farmanguinhos, the pharmaceutical laboratory of the Oswaldo Cruz Foundation was able to manufacture the first batch of efavirenz in January 2009 at 45 percent of the price set by Merck prior to the grant of compulsory licence.

146 PB Rutledge, 'TRIPS and BITS: An Essay on Compulsory Licenses, Expropriation, and International Arbitration' 13 NCJL \& Tech On 149 (2012) 149-164. See also 'Brazil to Produce Generic Version of Merck's Antiretroviral Efavirenz,' European AIDS Treatment Group (Sept. 18, 2008), $<$ http://www.eatg.org/news/162572/Brazil_to_produce_generic_version_of_Merck's_antiretroviral_efavirenz> accessed 28 March 2014

${ }^{147}$ CM Correa (n 125). Although the US criticised the action of granting compulsory license for the drug efavirenz as "...a major step backward," it did not pursue any trade sanctions against Brazil.

148 J Miller and G Anand, 'India Prepares EU Trade Complaint,' The Wall Street Journal (6 August 2009) $<$ http://online.wsj.com/article/SB124949598103308449.html?mod=googlenews wsj $>$ accessed on 16 April 2014; M Khor, 'Row Over European Seizure of Low-Cost Drugs', Third World Resurgence No.228/229 (AugustSeptember 2009) 4-5 <http://www.twnside.org.sg/title2/resurgence/2009/228-229/health1.htm> accessed on 16 April 2014.
} 
and not intended for sale within EU but destined to Latin American and African countries, included generic drugs used to treat AIDS, Alzheimer's disease, heart conditions, to name a few. The shipments were detained, at the request of transnational pharmaceutical corporations including Sanofi-Aventis SA, Novartis AG, and Eli Lilly \& Co, for periods extending for as long as eight months. ${ }^{149}$ The EC Regulation 1383/2003, tasks national customs offices with policing intellectual property laws on goods entering or transiting through their posts. Using the powers under the above Regulation, customs officials acted ex officio to initiate temporary seizures, and based on fictional patent violations, to impound and thereby delay shipments of life-saving medicines bound from India to countries in Africa, Latin America and Oceania. ${ }^{150}$ A shipment of the generic drug Losartan Potassium, used in the treatment of high blood pressure, destined for Brazil was also one of the consignments seized while in transit at Schipol Airport, in the Netherlands in December 2008, and was later returned to India, the country of origin. ${ }^{151}$

The India representative speaking at the TRIPS council meeting held on 27-28 October and 6 November 2009deemed the seizure in transit as one of many "serious impediments to access to medicines." "152 It was pointed out by the India representative that the seizure in transit incident was inconsistent with the Paragraph 6 System, as such seizure could prevent the hypothetical shipment of a generic drug from an exporting country to a least-developed country in a timely manner. ${ }^{153}$ The practice of seizure of medicines-in-transit for fictional violation intellectual property violation was strongly decried by scholars, ${ }^{154}$ as it violated core principles of the TRIPS Agreement. The above seizures and EU's delayed and defensive responses to repeated expressions of diplomatic and human rights concerns led both Brazil and India to seek consultations with the EU and the Netherlands before the Dispute Settlement Body in the WTO. ${ }^{155}$ Following negotiations amongst the parties, on 28 July 2011, the Government of India announced the reaching of an 'Understanding' in principle with the EU over the pending compliant before the Dispute Settlement challenging EU action regarding the seizure of generic medicines-in-transit. ${ }^{156}$ Whatever the outcome of the dispute before the WTO, the whole episode painted a very negative picture of the pharmaceutical patent holding developed countries within the EU who were using customs measures to impound generic drugs destined

\footnotetext{
${ }^{149}$ Miller \& Anand (n 148). See also BK Baker, 'Settlement of India/EU WTO Dispute Seizure of In-Transit Medicines: Why the Proposed EU Border Regulation Isn't Good Enough,' PIJIP Research Paper No.2012-02, American University Washington College of Law, Washington, DC (2012).

${ }^{150}$ Baker (n 149).

${ }^{151}$ Baker (n 149); S Lester, 'The Generic Drug Seizure Complaints' International Economic Law and Policy Blog (20 May 2010) <http://worldtradelaw.typepad.com/ielpblog/2010/05/the-generic-drug-seizurescomplaints.html> accessed 17 April 2014; DR Kanth, 'India, Brazil Drag EU to WTO’ Business Standard, Geneva (13 May 2010) <http://www.business-standard.com/article/economy-policy/india-brazil-drag-eu-to-wto110051300017_1.html> accessed 17 April 2014.

${ }^{152}$ Minutes of Meeting of the Council for TRIPS, WTO, held on 27-28 October and 6 November 2009 $<$ https://docs.wto.org/dol2fe/Pages/FE_Search/DDFDocuments/82087/Q/IP/C/M61.pdf > accessed 17 April 2014.

153 Ibid.

${ }^{154}$ HG Ruse-Khan and T Jaeger, 'Policing Patents Worldwide? EC Border Measures against Transiting Generic Drugs under EC- and WTO Intellectual Property Regimes' 40 Int'1 Rev Intell Prop \& Competition L (2009) 502; Baker (n 149). See also B Mercurio, "Seizing" Pharmaceuticals in transit: Analyzing the WTO Dispute That Wasn't,' International \& Comparative Law Quarterly 61 No 2 (2012) 389-426.

${ }^{155}$ Baker (n 149); Communication from the Brazilian delegation requesting consultations with the EU and with the Government of the Netherland before the Dispute Settlement Body at the WTO (19 May 2010) $<$ http://www.worldtradelaw.net/cr/ds409-1(cr).pdf> accessed 17 April 2014; Communication from the Indian delegation requesting consultations with the EU and with the Government of the Netherland before the Dispute Settlement Body at the WTO (19 May 2010) <http://www.worldtradelaw.net/cr/ds408-1(cr).pdf $>$ accessed 17 April 2014.

${ }^{156}$ Baker (n 149).
} 
for developing countries and LDCs, as it made a mockery of EU's commitment to access to medicines. Unfortunately, Brazil was in the receiving end of the above events, as legally produced life-saving generics medicines destined to its shores were seized in transit in a developed country, thereby denying access to medicines to the vulnerable patience in a developing country.

\subsubsection{Key Provisions 2: Prior Consent, ANVISA, and Second Use Medical Patent}

Following the CPI recommendations, Brazil adopted provisional measures amending the Industrial Property Law, establishing the mechanism of 'prior consent' in the examination of patent applications from pharmaceutical and chemical industry. ${ }^{157}$ This newly set up system saw the applications being scrutinised by INPI and the National Health Surveillance Agency of Brazil, or Agência Nacional de Vigilância Sanitária (ANVISA). ${ }^{158}$ In December 1999, Brazil's legislature passed the 'prior consent', or anuência prévia rule, which is contained in Article 229-C. ${ }^{159}$ This Article, sadly, offered little or no guidelines as to the 'shared competence' or duties of INPI and ANVISA in the scrutiny of patent applications for pharmaceutical and chemicals. ${ }^{160}$ On 14 February 2001, the Brazilian government passed Lei 10.196/01 amending Article 229-C to make 'prior consent' a permanent feature of its LPI and included the stipulation that the grant of all patents for pharmaceutical products and processes was subject to ANVISA's prior approval. ${ }^{161}$ Later, ANVISA issued a resolution (RDC-45) to clarify its competence in such matters regarding the examination of pharmaceutical patent applications. ${ }^{162}$ The INPI, an authority created in 1970 and charged with the scrutiny of the patent applications under the Industrial Property Law performs a different role to that of the ANVISA, but yet to a great degree its decisions are subject to the authority of the ANVISA, leading to a cumbersome and long drawn patent examination process in case of pharmaceutical and chemical patent applications. One should note, and not forget, that these two bodies are governed by different interests. ANVISA pursues the harmonization of the protection of intellectual property rights with the protection of public health by exploiting legal flexibilities offered under the TRIPS Agreement and the Doha Declaration, while INPI follows the guidelines contained in Brazilian intellectual property legislation (LPI)in line with the TRIPS

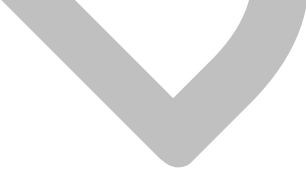

\footnotetext{
${ }^{157}$ Basso and Rodrigues $\operatorname{Jr}$ (n 122).

${ }^{158}$ ANVISA is a regulatory agency with independent administration and financial autonomy. Besides coordinating with the National Sanitary Surveillance System (SNVS) and monitoring drug products and medical device prices, it is also tasked with the 'patentability' examination for pharmaceutical patents along with the INPI. Its role is akin to that of the Food and Drug Administration (FDA) of the US.

${ }^{159}$ Article 229-C reads as follows: The concession of granting patents for pharmaceutical products and processes will depend on the prior consent of the National Agency of Sanitary Vigilance (ANVISA).

${ }^{160}$ KC Shedlen, 'The Rise and Fall of 'Prior Consent' in Brazil', The WIPO Journal, Vol. 3, Issue 1 (2011) 103112, 104. See also Basso and Rodrigues Jr (n 122).

${ }^{161}$ B Murphy, 'Brazil's Anuência Prévia: How Brazil's Unique Pharmaceutical Patent Law Illustrates that the United States and Brazil Continue to Disagree on TRIPS' Flexibilities to Protect Access to Essential Medications,' (2005) 1-16, <www.ssc.wisc.edu/ munia/467/BrazilMurphy.pdf $>$ accessed 9 April 2014. The author refers to the creation of anuência prévia as a 'shotgun wedding' requiring the two distinct government agencies, INPI and ANVISA, to work together in the examination and granting of pharmaceutical patents.

162 Basso and Rodrigues Jr (n 122). Resolution RDC-45 was issued on 23 June 2008. Going by the explanations presented under RDC-45, INPI will first carry out substantive assessment of the requirements and conditions of patentability and forward the processes it believes may be eligible for protection to ANVISA. Following which, ANVISA will carry out an examination of the processes to satisfy the requirement of the Industrial Property Law and decides to either grant or not grant a patent to the invention.
} 
Agreement. ${ }^{163}$ Some authors have expressed the view that prior consent process introduced by Brazil is keeping in line with the TRIPS Agreement. ${ }^{164}$

Working of the ENVISA demonstrates that it does not grant prior consent to i) applications filed with insufficient description, ii) claims from Markush ${ }^{165}$ groups, iii) selections of chemical macrostructures, iv) polymorphs, v) raceme/isomeric mixes, and vi) second medical use patent claims. ${ }^{166}$ ANVISA, in a report issued in 2004, clarified that it will not grant prior consent filings related to second use patents, which is contradictory to the policy of protecting second and new use patents by the INPI. ${ }^{167}$ This brings us to the discussion on granting of patents based on second and subsequent use. Supporters of the second and subsequent use patents argue that they protect discoveries of new uses for substances, active principles, molecules, or compounds that have been previously patented or are already in the public domain. ${ }^{168}$ Subsequent patent use involves new prescribed functions of pharmaceuticals already known and used within the medical community for different purposes. ${ }^{169}$ In effect, a second or subsequent medical use patent, if granted, protects the discovery of a new medical application for a product that has already been recognised and utilized in the medical field. ${ }^{170}$ The other major argument used by supporters of second use patents is that the human and economic investment incurred by the pharmaceutical industry to discover a second use is comparable to the investment necessary to develop the product or drug as such, and hence the need for recognition. ${ }^{171}$ In the UK the position on grant of second and subsequent use pharmaceutical patent ${ }^{172}$ was upheld in Actavis v Merck ${ }^{173}$ where the Court of Appeal came to revisit the position on patentability of dosage regime regarding Merck's patent for a drug used in male pattern baldness. The European regulatory legislation as originally drafted (EPC 1973) facilitated access to generic drugs within the European Union (EU), but an interpretation of

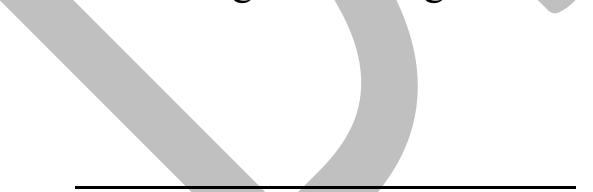

${ }^{163}$ EB Rodrigues Jr and B Murphy, 'Brazil's Prior Consent Law: A Dialogue Between Brazil and the United States Over Where the TRIPS Agreement Currently Sets the Balance Between the Protection of Pharmaceutical Patents and Access to Medicines,' 16 Alb. L.J. Sci. \& Tech. (2006) 423-456, 429. See also Basso and Rodrigues $\operatorname{Jr}(\mathrm{n} 122) 79$.

${ }^{164}$ Chaves, et al (n 129). The authors argue that prior consent is in full compliance with Article 8 of the TRIPS Agreement, which permits members to adopt necessary measures into their domestic laws to protect public health and promote the public interest in sectors of vital importance to their socio-economic and technological development.

165 The term 'Markush group' refers to a list of 'alternatives' set forth in a claim, and is named after Eugene Markush who successfully used a claim form that defined a genus by enumeration of the species in the 1920's [1925 CD 126 (Comm'r Pat.1925)]. Markush-style claims can be a way to explicitly claim a large number of variations of the claimed invention. M Cicero, 'Markush Groups' (17 October 2012) $<$ http://www.ruttlerlaw.com/blog/2012/10/markush-groups/> accessed 10 April 2014.

166 Basso and Rodrigues Jr (n 122) 80.

${ }^{167}$ Rodrigues Jr and B Murphy (n 163).

${ }^{168} \mathrm{O}$ Mitnovetski and D Nicol, 'Are Patents for Methods of Medical Treatment Contrary to the Ordre Public and Morality or "Generally Inconvenient"?', 30 J. Med. Ethics (2004) 470-477, 472 $<$ http://jme.bmj.com/content/30/5/470.full.pdf> accessed 9 April 2014.

${ }^{169}$ Ibid; Rodrigues Jr and B Murphy (n 163).

170 Rodrigues Jr and B Murphy (n 163) 430.

${ }^{171}$ Rodrigues Jr and B Murphy (n 163) 431.

172 Second and subsequent medical use patents are now expressly permitted under section 4A (4) of the Patents Act 1977, provided the claim is in the form 'substance $x$ for use in the treatment of disease y', following the Enlarged Board of Appeal of the European Patent Office's G2/08 Kos decision.

${ }^{173}$ Actavis UK Ltd v Merck \& Co Inc [2008] EWCA Civ. 444. Jacob LJ observed that "Research into new and better dosage regimes is clearly desirable, and that there is simply no policy reason why, if a novel non-obvious regime is invented, there should not be an appropriate patent reward". See also the Court of Appeals decision in Hospira UK Ltd and Generics UK Ltd v Novartis AG [2013] EWCA Civ 1663. 
new laws from 2000 by the Enlarged Board of Appeal (EBA) does not exclude second or subsequent use pharmaceutical patent. ${ }^{174}$

In practice the pharmaceutical corporations often use the second use as a tool to extend the commercial life of patents, which strategy is widely referred to as evergreening, thereby maximising on the monopoly period enjoyed by the patented drug. ${ }^{175}$ The practice of evergreening considerably delays, and poses a threat for the legal entry of generics into the market, and can successfully prevent competition in the pharmaceutical market, although some pharmaceutical corporations do believe that the term evergreening is pejorative and is misleading. ${ }^{176}$ Recent Brazilian court decisions have sent out mixed signals on ANVISA's role in the scrutiny of pharmaceutical applications. ${ }^{177}$ One decision, in particular delivered in $2013,{ }^{178}$ has held that it is possible to grant patent protection for items not listed as nonpatentable in Lei $9.279 / 96$, which technically threw the door open for seeking protection on second and subsequent use pharmaceutical patents. If the judicial trend of granting patents to second and subsequent use are to continue, Brazil may find itself in a very sticky wicket as it will potentially harm its HIV/AIDS programme, which is strongly reliant on generic drugs. Granting of second and subsequent use medical patents will see a huge price rise in pharmaceutical products, and can spell the death knell to the access to medicines programme

${ }^{174}$ Article 52(4) EPC 1973 and Article 53(c) EPC 2000. Under EPC 1973 inventions in order to be patentable must be 'susceptible of industrial application.' Article 52(4) clearly states that the fiction that medical methods are not so susceptible. Whereas Article 54(5) provides for a special exception for medical products to the normal novelty rules by stating that if 'its use for any (medical treatment) method is not comprised in the state of the art'. Under EPC 2000, which came into effect from 13 December 2007, introduced changes in this regard. Article 53 (c) seeks to remove the fiction about industrial applicability, and declares that patents may not be granted for medical methods. This presented a dilemma which was resolved by the EBA in G0005/83 (Eisai) and related cases. The EBA concluded that Art 54(5) of EPC did not exclude second (and further) medical indications from patent protection 'other than by a purpose-limited product claim'. In October 2004 the EPO's Technical Board of Appeal in T1020/03 in a review of G0005/83 went further, and concluding that protection is not limited to new indications, which may extend to protecting a product for use in any novel and inventive therapy. The UK Patent Act 2004 implemented EPC 2000.

175 JM Mueller and DS Chisum, 'Enabling Patent Law’s Inherent Anticipation Doctrine' (2008) 45(4) Hous L Rev 1101, 1106-1107; R Feldman, 'Rethinking Rights in Biospace' (2006) 79 S Cal L Rev 1, 30; JO Lanjouw, 'A New Global Patent Regime for Diseases: US and International Legal Issues’ (2002) 16 Harv JL \& Tech 85, 9495. Here, the author defines the practise of 'evergreening' resorted to by pharmaceutical corporations. See also ME Furrow, 'Pharmaceutical Patent Life-Cycle Management after KSR v. Teleflex' (2008) 63 Food \& Drug LJ 274.

176 GlaxoSmithKline, 'Evergreening', Global Public Policy Issues (August 2011) $<$ http://www.gsk.com/content/dam/gsk/globals/documents/pdf/GSK-and-evergreening.pdf $>\quad$ accessed 28 February 2013.

177 On 24 January 2012, in response to a writ of mandamus, Judge Solange Salgado of the First Federal Court in Brasilia, ruled that ANVISA when faced with a request for prior approval, while examining pharmaceutical examination, must restrict itself only to public health issues. This decision appears to restrict the authority of ANVISA to examine patentability requirements. Similarly, on 25 January 2012, the Chief Appellate Judge Jiriar Aram Meguerian of the Court of Appeals for the first Circuit, rejected ANVISA's motion regarding prior approval. The Appellate court held that the greater objective of Article 229-C was to grant the possibility of ANVISA to guard against patents for pharmaceutical products and processes when faced with Article 18, Item I of the Industrial Property Laws. Both decisions seem to check the unfettered freedom of authority enjoyed by ANVISA. O Licks, 'Brazilian Courts Fight to Fix TRIPS Violations' World Intellectual Property Review (1 February 2012) $<$ http://worldipreview.com/article/brazilian-courts-fight-to-fix-trips-violations> accessed 11 April 2014.

178 The Brazilian Court in Rio de Janeiro, Brazil (Primeira Seção Especializada do Tribunal Regional Federal da $2^{a}$ Região) was deciding on an appeal against the rejection of a patent application for second use pharmaceutical patent. But, the Brazilian Patent Office has not released any official statement or guidelines following the decision of the court, which makes one suspect that this could be seen as an isolated case. See Balder IP Law, 'Favourable Decisión of a Brazilian Court Allowing Patent Protection for Second Medical Use Claims' (4 August 2013) $<$ http://balderip.com/favourable-decision-of-a-brazilan-court-allowing-patent-protection-for-second-medicaluse-claims/> accessed 11 April 2014. 
put in place by the Brazilian government following its commitment to health as a constitutional right, as the goals will likely become unachievable. As seen from a number of decisions taken by ANVISA, its position is clearly not in favour of granting second and subsequent use medical patents. India, another developing country and also a major generics drugs manufacturer, introduced TRIPS compliant patent laws in 2005, thereby moving from a process patent regime to a product patent regime. The new patent law introduced by India included such provisions to check the practice of ever-greening, which effectively outlaws granting of second and subsequent use pharmaceutical patents, ${ }^{179}$ which provisions were upheld by the Supreme Court of India in the Novartis ${ }^{180}$ case decided in 20013.

From the above discussion it can be inferred that the system of prior consent introduced to prevent the exploitation of the patent system by transnational pharmaceutical corporations had come under severe scrutiny, with some appreciating the measures ${ }^{181}$ taken by Brazil and others criticising the practice on the premise that it has led to divergent decisions being taken on pharmaceutical patent applications. ${ }^{182}$ Although the arrangement was initially welcomed by INPI, the relationship of the two organisations was to deteriorate in the years that followed, with the INPI failing to acknowledge ANVISA's role in the 'prior consent' process. ${ }^{183}$ The ANVISA for its part introduced measures to reassert its authority over the patent office. ${ }^{184}$ The ANVISA had received a very strong and active support from civil society groups who were interested in furthering the cause of the Brazil's AIDS programme, and integration of peoples programme. ${ }^{185}$ The domestic pharmaceutical sector originally welcomed the 'prior consent' process when introduced in 2001, but later on was not so keen to promote the cause of the same. ${ }^{186}$ This change in stance was clearly due to the fact that there was a bias against the grant of patents for incremental innovations, ${ }^{187}$ which was detrimental to domestic pharmaceutical companies, as incremental innovation was seemingly the only option available for growth. ${ }^{188}$

The involvement of ANVISA in the scrutiny of pharmaceutical patents is viewed as the main reason for the backlog before the Brazilian Patent Office, and it is clear that this process has largely slowed down the grant of patents. Brazil has come under tremendous external pressure due to the introduction of 'prior consent,' although the process as a mechanism in the

179 Sundaram (n 22).

${ }^{180}$ Novartis Ag v Union of India \& Others [2013] 6 SCC 1.

${ }^{181}$ CM Correa, 'Guidelines for the Examination of Pharmaceutical Patents - Developing a Public Health Perspective', WHO-ICTSD-UNCTAD Publication (2007); Drahos (n.93) 248. See generally Deere (n 12). See also Shedlen (n 160).

${ }^{182}$ VYM Kunisawa, 'Patenting Pharmaceutical Inventions on Second Medical Uses in Brazil,' Journal of World Intellectual Property, Vol.12, No. 4(2009) 297-316. The author has taken up for study the granting of pharmaceutical patents focussing on patentability of second medical use of known substances.

183 Shedlen (n 160) 104-105.

${ }^{184}$ Shedlen (n 160) 105-106. The author is of the view that the conflict between INPI and ANVISA was more a standard intra-bureaucratic rivalry, with the patent office resenting the interference of health authorities into its territory. Later, the conflict between the two bodies went beyond the definition of a turf-war, as ANVISA's examination of certain types of pharmaceutical patent applications was critical and thereby restrictive of the scope of patentability.

185 Shedlen (n 160) 109-110.

186 Shedlen (n 160) 109-110.

${ }^{187}$ Article 8 Lei 9279/96 (LPI) reads as follows: An invention shall be patentable if it meets the requirements of novelty, inventive step and industrial application. Note: Article 11 states an invention or utility model shall be considered to be new if it does not form part of the state-of-the-art. Likewise inventive step is identified in Article 14, and industrial application in Article 15. Apart from the above, Article 24 requires any application for a patent of invention or utility model to be thoroughly described, so as to allow its reproduction by one skilled in the art. ${ }^{188}$ Shedlen (n 160) 110. See also M Cassier and M Correa, 'Intellectual Property and Public Health: Copying of HIV/AIDS Drugs by Brazilian Public and Private Pharmaceutical Laboratories’ 1 RECIIS -Elect. J. Commun. Inf. Innov. Health V.1, No.1 (2007) 83-90. The authors present a study of five Brazilian pharmaceutical laboratories, and are critical of the practice of generics drugs manufacturing through reverse engineering. 
scrutiny of patent application appears to be acceptable under the TRIPS Agreement. ${ }^{189}$ While analysing the pros and cons of the 'prior consent' process, one should take on board the fact that it was introduced by the Brazilian government into its intellectual property legislation as part of its commitment in its vision to provide free public health at a time of crisis, and on the premise that patents for pharmaceuticals are different from patents for other technologies due to their implications on public health and special relationship with society. ${ }^{190}$ With growing opposition from within and without, Brazil has boldly continued with the practice on the back of popular support from its citizens and civil society groups and other NGOs. Proposals for reforms announced by the Brazilian government to the patent law provisions, their possible consequence to the existing system, and the knock-on effect on the access to medicines programme and the HIV/AIDS programme are discussed in the later part of this study.

\subsection{Access to Health \& Medicines \& Judicial Enforcement: Trouble in Paradise}

Brazil's health care programme strongly hinges on three principles of, right to health guaranteed under the constitution, establishment of HIV/AIDS programme, and last but not least a dynamic TRIPS compliant patent law that facilitate the domestic production and purchase of generics for its health services. In the absence of any of the aforementioned, the health care programme is bound to fail. With a population of over 190 million and with one of the largest pharmaceutical markets in the world, Brazil spent more than US\$17 billion on medicines in 2009. ${ }^{191}$ Despite the above, the general population's access to health services and the quality of such services varies according to geography, income and government resources. ${ }^{192}$ The populations can also be classified under three heads based on income groups, with the top grossers forming only 15 per cent of the population yet consuming close to half of the pharmaceuticals sold in Brazil, and the poorest making for 51 per cent of the population but yet consuming a meagre 16 per cent of the pharmaceutical sold in Brazil. ${ }^{193}$ The middle income groups make for 34 per cent of the population and purchase around 36 per cent of all pharmaceuticals sold. ${ }^{194}$ The HIV/AIDS programme introduced in Brazil was a success to begin with, but strains were felt due to the uneven pace between the emergence of new pharmaceutical products within the healthcare system, and the acute need for new front line treatment for patients who were resistant to existing drugs, ${ }^{195}$ which was despite the fact Brazil was able to use the 'national emergency' clause to facilitate local production of ARVs. ${ }^{196}$

As medicines became scarce or unavailable under the SUS, many Brazilians were constrained to resort to the courts to enforce their constitutional right to health, with an ever increasing volume of individual right-to-health lawsuits being filed on a daily basis. ${ }^{197}$ The

189 Shedlen (n 160) 112. The author attributes external pressure in the form of US Special 301 reports, the Washington-based Pharmaceutical Research and Manufacturers of America, and from transnational pharmaceutical firms operating in Brazil.

${ }^{190}$ Murphy (n 161).

${ }^{191}$ J Biehl, JJ Amon, MP Socal, and A Petryna, 'Between the Court and the Clinic: Law Suits for Medicines and the Right to Health in Brazil' Health \& Human Rights: An International Journal, Vol. 14 No.1 (2012) 36-52.

192 Cohen and Lybecker ( $\mathrm{n} 88$ ) 215. The authors also mention that the nearly 74 per cent of the population, who the clients of the SUS, are also the ones who cannot afford to pay for a private medical care.

193 Cohen and Lybecker (n 90) 216.

${ }^{194}$ Cohen and Lybecker (n 90) 216.

195 Chaves, et al (n 129) 9-10.

${ }^{196}$ Cohen and Lybecker (n 90) 217. The authors refer to studies made in 2002 which showed that 47 per cent of ARVs required for the treatment were acquired from domestic firms, while 53 per cent of ARVs were acquired from international pharmaceutical companies.

${ }^{197}$ Biehl et al (n 191). Right to health litigation is a widespread practice in south eastern and southern Brazil, where judicialization is seen as an alternative pathway for accessing healthcare. In 2009, 5,536 cases relating to the right to health challenging high court rulings reached the Superior Court of Justice, and about half of these cases $(2,583)$ were for access to medicines. In the same year, the Federal Supreme Court of Brazil heard 806 cases 
dramatic increases in law suits over the decade have seen the Federal Health Ministry's spending on court-attained medicines go up exponentially. ${ }^{198}$ The first of the law suits to be filed was in 1996, where the courts ruled in favour of the claimant/patient. The reliefs sought in the above law suits normally focussed on a demand for medicines included on the Ministry of Health but not available, medicines not on the list due to high costs, and medicines that have not yet been established as safe and effective under the health care system. ${ }^{199}$ Invariably, in all the cases the Brazilian courts were inclined to grant the relief sought for and order the State to provide the medicines sought, as the judicial consensus is that a denial of medicine is a violation of the constitutional right to health and access to medicines. ${ }^{200}$ The Brazilian courts, including the Supreme Federal Tribunal or, Supremo Tribunal Federal (STF), consider the right to health as an individual entitlement to the satisfaction of all of one's health needs with the most advanced treatment available, regardless of the cost implications to the system. ${ }^{201}$ The decisions handed down by the STF portray the judiciary as a powerful tool for protecting the constitutional right to health, and in the Court's understanding of its role, such lawsuits protect citizens against government irresponsibility and omission in regards to health issues. ${ }^{202}$

However, a slight shift in trend was noticeable in recent years in the decisions handed down by the STF. ${ }^{203}$ Some have argued that this approach of the Brazilian courts to invariably grant the relief sought for in the claims does not take into account the economic constraints of the Brazilian system to deliver universal health. ${ }^{204}$ Most cases that have reached the STF, relate to anti-HIV treatment, followed by phenylketonuria, Duchenne muscular dystrophy and cancer treatment. ${ }^{205}$ In February and March 2007, the STF delivered two decisions, denying claims for access to medicines. The then President of the STF, Ellen Gracie, was quoted as saying, "...It is my understanding that Article 196 of the Constitution, that assures the right to health, refers mostly to the carrying out of policies that reach the population as a whole, assuring them universal and equal access, and not in individual situations. The responsibility of the State to provide the resources necessary to the health care of its citizens cannot endanger the public health System." The NGOs and the civil society groups in Brazil reacted strongly to the above two decisions of the STF and advocated a strong right to health campaign, while local health officials seized the mood of the judiciary to bring court actions to interrupt medicine provisions previously ordered by the courts. ${ }^{206}$ The judicial trend that followed demonstrated a change, as in some cases it reverted to the earlier pattern of granting claims for access to medicines. ${ }^{207}$

related to the right to health, of which 142 were for access to medicines. See also HV Hogerzeil, M Samson, JV Casanovas, and L. Rahmani-Ocora, 'Is access to essential medicines as part of the fulfilment of the right to health enforceable through the courts?' The Lancet 368/9532 (2006) 305-311.

${ }^{198}$ Biehl et al (n 191). The authors note that the Federal Health Ministry, in 2009, spent US\$47.8 million on courtattained drugs, which is a significant increase from the US\$20.4 million spent in 2008 and US\$4.2 million spent in 2007. The same ministry, in 2003, spent just under US\$59,000.

${ }^{199}$ Rosina, et al (n 75) 107.

${ }^{200}$ Rosina, et al (n 75) 107.

201 OLM Ferraz, 'The right to Health in the Courts of Brazil: Worsening Health Inequities?' Health and Human Rights (2009) 33-45.

${ }^{202}$ Rosina, et al (n 75) 110.

${ }^{203}$ Ferraz (n 201). The author also points out that in recent years the trend has been changing. See also Rosina, et al (n 75) 110, where the authors point out to a shift in the pattern of decisions by the STF regarding individual demands for medicines or medical treatments, as the courts started to deny some petitions recognizing public resource limitations, administrative funding allocations, etc. Whereas, precedents from earlier STF decisions demonstrated an understanding of budgetary considerations as a "secondary governmental interest" and of "minor importance."

${ }^{204}$ Ferraz (n 201).

${ }^{205}$ Rosina, et al (n 75) 109.

${ }^{206}$ Rosina, et al (n 75) 111.

${ }^{207}$ Rosina, et al (n 75) 111. The authors note that from mid-2007 onwards some decisions of the STF had continued with the new approach, while others follow the pre-2007 traditional one, demonstrating a lack of predictability 
The key driving force behind the ongoing process of implementing the policy of free access to ARVs in Brazil is down to the support this policy receives from civil society groups and NGOs who have mounted a ceaseless campaign all along, which has also to a greater degree helped maintain pressure on the courts in Brazil to consistently grant judicial orders for claims seeking access to medicines as a constitutional right.

\subsubsection{Brazil's Balancing Act: The Current State of Play and Proposed Changes}

Brazil's vision and implementation of constitutional right to health and access to medicine, and its HIV/AIDS programme is commendable. It had held steadfastly to its stance amidst external pressure from developed countries and transnational pharmaceutical corporations to deliver its commitment to right to health, access to medicine and anti-AIDS programme. In the face of opposition it had successfully manoeuvred through the troubled waters of generic medicines and international intellectual property rights enforcement regime to make medicines affordable to its citizens. While all these actions are laudable, one cannot fail to notice that Brazil acted hasty in its implementation of the TRIPS flexibilities, which proved to be costly. Although it managed to recover, it did not fully implement the flexibilities. For instance, it did not introduce any clear legislation to prevent/check the practice of patent evergreening by transnational pharmaceutical corporations. This is one area where it needs carry out more work, as transnational pharmaceutical corporations are notorious in the practice of evergreening and are known to take advantage of the TRIPS Agreement to seek extended patent protection in fast growing pharmaceutical markets like Brazil, India, Thailand, and South Africa. While it can be argued that second and subsequent pharmaceutical patent is hardly ever granted in Brazil due to the 'prior consent' process and the involvement of ANVISA in the examination of pharmaceutical patent applications, it still lacks in not having a legislative framework which is capable of laying down clear laws to protect the Brazilian jurisdiction from the abuse of patent evergreening. In other words the protection offered against such practices is only procedural and not explicit in law. Brazil will benefit from the introduction of similar provisions as section 3(d) of the Indian Patent Act to counter the threat of the practice of evergreening.

That apart, one will also have to look at the track record of Brazilian courts in dealing with such cases challenging the decisions of ANVISA in rejecting pharmaceutical patent applications on the grounds of second and subsequent medical use. Clearly defining the role of ANVISA will go a long way in the establishment of a reliable mechanism for scrutiny of pharmaceutical patent applications. Also, a number of suits were filed in Brazil, particularly from the southern and south eastern parts of Brazil, seeking the courts directive to access medicines. The STF's decision, which used to be consistent, started showing a change in the approach from the beginning of 2007, as it came under severe pressure from both civil society groups and local health officials. The judicial trend, which was discussed in the earlier section, still remains a cause for concern as the decisions handed down by the STF are not consistent. To be able to successfully implement any policies and laws, a country needs to boast of a robust judiciary which will not be fazed by external pressure and be able to pronounce the law in the light of its true purport in the pursuit of justice. In 2013, the Brazilian government announced proposals for change to its industrial property laws, and the same is analysed in the next section.

Changing Landscape and the Proposed Changes to Patent Laws: In December 2013 a key administrative change at the INPI was announced, which means that one of the long serving commissioners will be replaced by a career diplomat, branded as holding strong views

in such matters. See also Biehl et al (191), where the authors note that 815 cases out of the 917 cases that had reached a state high court received a favourable ruling for the plaintiff (either partial or full provision of drugs), which represents a success rate of 89 percent. 
about the patent system, and in particular towards pharmaceutical patents. ${ }^{208}$ The new commissioner has already welcomed and supported the new bill (5.402/2013), which proposes extensive changes to the 1992 industrial property laws. ${ }^{209}$ The changes proposed are clearly influenced by the Indian Patent Act 2005, in seeking to lower the level of patent protection and at the same time raising the bar on patentability. On 9 October 2013, the Brazilian Parliamentary Committee released the proposals for change to its industrial property laws in a report entitled 'Brazil's Patent Reform: Innovation Towards National Competitiveness. ${ }^{210}$ The reforms include eliminating patent term extensions and data exclusivity, restricting patents on new forms and second and subsequent use pharmaceutical inventions, increasing the standard for inventive step, ${ }^{211}$ and also clarify the role Brazil's drug regulatory agency (ANVISA) besides strengthening its prior approval powers to deny pharmaceutical patents. Article 2 of Bill HR 5042/2013 restricts patent protection to a 20-year period and seeks to scrap Article 40 of Lei 92790/1996 which grants patent protection beyond 20 years where the time taken for granting a patent exceed 10 years. This is a TRIPS compliant provision, as Article 33 of the TRIPS Agreement does not envisage grant of patent beyond a period of 20 years starting from the date of filing, and any further extension of patent beyond the period mentioned in Article 33 is a 'TRIPS-plus' measure ${ }^{212}$

The next important reform proposed is under Article 3 of the above bill, which seeks to amend Article $10(\mathrm{X})$ and (XI) to exclude certain items from patentable subject matters, and runs as follows:

Art. 10. [The following are not considered to be inventions or utility models:]

(X) any new property or new use of a known substance, or the mere use of a known process, unless this known process results in a new product;

(XI) new forms of known substances that do not result in an improvement in the known efficacy of the substance.

For the purposes of this Article, salts, esters, ethers, polymorphs, metabolites, pure form, size of particles, isomers, mixtures of isomers, complexes, combinations and other derivatives of a

${ }^{208}$ W New, 'Brazil Takes Steps Aimed at More Balanced IP Rights,' Intellectual Property Watch (13 December 2013) < http://www.ip-watch.org/2013/12/13/brazil-takes-steps-aimed-at-more-balanced-ip-rights/> accessed 9 April 2014. Otavio Brandelli, the incoming commissioner is viewed as an advocate for the 'agenda for development' that Brazil presented with Argentina at the WIPO. The author quoting Allan Rocha de Souza (cultural policy professor at Federal University of Rio de Janeiro) opines that this appointment signals that Brazilian internal and foreign policies on patents will finally be bridged, as the new commissioner Brandelli has a good foreign affairs experience.

209 O Licks, 'Brazil: What to Expect in 2014,' World Intellectual Property Review (1 February 2014) $<$ http://www.worldipreview.com/article/brazil-what-to-expect-i-2014> accessed 11 April 2014.

${ }^{210}$ Brazil's Patent Reform: Innovation Towards National Competitiveness, (Center for Strategic Studies and Debates 2013) ISBN 978-85-402-0107-1 (e-book). The report was presented following extensive consultation carried out over seven workshops conducted between 2011 and 2013. See also V Srinivasamani and A Ramanujan, 'Brazilian Patent Law: Proposed Reforms Inspired by Indian Law' IPR Amicus Issue 28 (November 2013).

${ }^{211}$ More in line with section 3(d) of the Indian Patent Act 2005, and following the decision of the Indian Supreme Court in Novartis Ag v Union of India \& Others [2013] 6 SCC 1.

${ }^{212}$ Article 33 of TRIPS Agreements reads as follows: The Term of protection available shall not end before the expiration of a period of twenty years counted from the filing date. There is no requirement under the TRIPS Agreement for patent term extensions to compensate for regulatory delays, either in the granting of a patent or, in the registration/marketing approval of a medicine. The term of 20 years was adopted in substantial part to compensate for customary periods of regulatory delay. See InfoJustice 'Brief Technical Review of Brazil's Proposed Patent Law Reforms’ (2013) <http://infojustice.org/wp-content/uploads/2013/10/Brief-TechnicalReview-of-Brazilian-Leglislation.pdf $>$ accessed 28 March 2014; Srinivasamani and Ramanujan (n210). 
known substance shall be considered the same substance, unless they significantly differ in terms of properties regarding efficacy.

The proposal in Article 3 is very similar to section 3(d) of the Indian Patent Act 2005, which has come under severe attack and criticism from transnational pharmaceutical corporations and also from the USTR, as it is a measure introduced by the Indian legislature to counter the practice of evergreening. ${ }^{213}$ Not surprisingly, the stated purpose of the above provision in the report is to prevent the practice of evergreening, used by pharmaceutical corporations to extend the lifetime of patents on the basis of minor or trivial changes to a known substance or on the basis of easily discovered new uses of existing substances. The "efficacy" standard suggests that there may be an inventive step worth patenting if the product shows significant or dramatic improvement in therapeutic efficacy. ${ }^{214}$ The number of patents granted in Brazil from 2000 to 2011 to overseas interests stood at 197,272 (69 percent) as opposed to, 88,096 to domestic interest ( 31 percent). ${ }^{215}$ The proposal to increase the standard of inventive step through Article 3 of the bill by amending Article 31 will strengthen the patent system, and together with the introduction of changes to second and subsequent use pharmaceutical patents see a well-protected patent regime immune to pharmaceutical patent abuse by transnational patented holders and also less applications from overseas patent interests. The changes mooted are similar to section 2(ja) of the Indian Patent Act, and the report also refers to steps taken by other jurisdictions, namely the US, to tighten-up the inventive step analysis to avoid granting of 20-year monopolies on minor or trivial advances in the art. ${ }^{216}$ The proposal to clarify the institutional structure and authority of ANVISA, especially relating to examination of pharmaceutical patents by INPI and ANVISA under the prior consent system will strengthen institutional credibility of the patent office. One can see the direction in which the Brazilian government wants to go in this regard, as it has started collaborating with other developing countries and sharing valuable experience in dealing with instances of evergreening and exploitation of patent regimes by transnational corporations.

\section{PART 4}

\section{Conclusion}

A year after the establishment of the WTO, the Joint United Nations Programme on HIV and AIDS (UNAIDS) was established, ${ }^{217}$ as the HIV/AIDS epidemic that had spread across the globe at an alarming rate was posing further threats, as the most affected regions in the developing countries and LDCs were only seeing an increase in numbers. ${ }^{218}$ When Brazil

\footnotetext{
213 The constitutional validity of section 3(d) of the Indian Patent Act was upheld by the Supreme Court of India in Novartis Ag v Union of India \& Others [2013] 6 SCC 1. See Sundaram (22) for a discussion of the Indian Supreme Court's decision. See also Brazil's Patent Reform: Innovation Towards National Competitiveness (n 210) 111-129.

${ }^{214}$ Brazil's Patent Reform: Innovation Towards National Competitiveness (n 210) 111-129. See also InfoJustice (210).

${ }^{215}$ O Licks, 'IPR Strategy in Brazil,' Licks Avagados, presentation made at the $4^{\text {th }}$ LES Asia Pacific Regional Conference, Hangzhou, Peoples Republic of China (17 October 2013) $<$ http://www.leschina.cn/files/LESAP2013/2013102308.pdf> accessed 28 March 2014.

${ }^{216}$ Brazil's Patent Reform: Innovation Towards National Competitiveness (n 210) 61-69. See also InfoJustice (210).

${ }^{217}$ UNAIDS was established in 1994 through a resolution of the UN Economic and Social Council and launched in January 1996. A member of the United Nations Development Group, UNAIDS, primary aim is to help mount and support an expanded response to HIV/AIDS.

${ }^{218}$ Z Lazzarini, 'Making Access to Pharmaceuticals a Reality: Legal Options Under TRIPS and the Case of Brazil' Yale Hum Rts \& Dev LJ 6 (2003) 103-138, 106. Since 1996, in developed countries, HIV/AIDS has become akin
} 
implemented TRIPS compliant patent legislation into its laws it already had in place a policy of universal access to ARV treatment following the HIV/AIDS epidemic that gripped the country in the mid 1980's. The above policies read with the constitution right to health guaranteed under the 1988 Constitution meant that the government had a herculean task at hand, which was the production of affordable medicine, or in other words generics, to honour its commitments. Unfortunately, Brazil went ahead with the implementation of the TRIPS legislation in a hurry without utilising the time-bound flexibilities afforded under the TRIPS Agreement. This saw Brazil finding itself in a very difficult situation. ${ }^{219}$ But, what it had proved since then is commendable, as it has seen a decrease in mortality rates between 1997 and 2004, which continues to decrease, and also reduction in morbidity from 1993 to 2003. It had also seen a reduction in the rate of hospitalisations, which has in turn generated a cost saving of close to US $\$ 2.3$ billion. These figures demonstrate that access to proper ARV treatment in Brazil over the past 10 years has substantially transformed the lives of patients and the methods of controlling HIV infection, improving quality of life for people living with AIDS, increasing their life expectancy, reduction of the transmissibility of the virus, and thereby causing a significant decline in mortality rates. ${ }^{220}$

Brazil, in its pursuit of universal health to its citizens has followed a pattern of bold policy decisions backed up by legislation and the creation of appropriate institutional mechanism to implement such policies. The changes proposed to the industrial property laws in 2013, and likely to be taken up for discussion in 2014, is encouraging as they appear to address the shortcomings of some of the provisions of the current laws, for example, the practice of seeking patent protection for second and subsequent use medical use, or evergreening. This area still remains a concern for Brazil's industrial property laws, as it not only currently lack necessary legislation to check such practices, but also has a peculiar system of 'double scrutiny' of pharmaceutical applications by the INPI and ANVISA, referred to as prior consent system, which has created huge ten year backlog. Working closely with civil society groups and NGOs, Brazil has managed, so far, to ward off external pressure from transnational pharmaceutical corporations and the US, which had used its super $301^{221}$ and the WTO's dispute settlement mechanism against it, and successfully continued with the implementation of its much acclaimed anti-AIDS programme. If one were to look closely at the time line from the outbreak of the AIDS in the 1980's in Brazil up to the point of the TRIPS

to other treatable chronic illnesses. In sharp contrast in the developing countries and LDCs, it still remains a deadly plague.

${ }^{219}$ S Ganji, TRIPS Implementation and Strategic Health Policy in India and Brazil, Joseph Korbel Journal of Advanced International Studies (2011) 29-57. The author observes that in implementing the TRIPS Agreement, India reacted to Western pressures by implementing the agreement in a gradual fashion, whereas Brazil enacted the Agreement in a hurried fashion. As a result, India's legal system was better positioned to deal with new global patent laws than Brazil's, which instead exercised its own brand of economic coercion (threat or use of compulsory licensing) to retrieve ground previously lost when it first ratified the TRIPS Agreement.

${ }^{220}$ Chaves, et al (n 129) 171.

221 The US Trade Representative cites powers granted to ANVISA to review pharmaceutical patent applications for meeting patentability requirements, which regulations according to the USTR appear to contravene an earlier opinion of the Federal Attorney General that ANVISA did not have the authority, as the primary reason in its 2013 report to keep Brazil on its 'watch list' of countries whose intellectual property regimes are of concern. The US has, year after year, identified the authority granted to ANVISA as one of the reasons for having Brazil in its Special 301 watch list. See Office of the U.S. Trade Representative, Special 301 Reports 1989-2014 (USTR, Washington DC, 2014) <http://www.keionline.org/ustr/special301> accessed 16 April 2014. The USTR has a 'priority watch list' and a 'watch list' to monitor countries around the world in their implementation of intellectual property rights. It should also be pointed out that Brazil was in the 'priority watch list' for a number of years before being put on the 'watch list.' India, another developing country, which used the TRIPS flexibilities to introduce section 3(d) into its patent legislation to check the practice of patent evergreening has been put on the 'priority watch list.' The USTR identifies the decision taken by the Intellectual Property Appellate Board (and confirmed by the Supreme Court of India) as one of the main reasons for putting India on the 'priority watch list.' 
implementation, it can be observed that all measures taken by Brazil had been within the international legal framework, and clearly TRIPS compliant. Although the TRIPS Agreement only recognizes intellectual property right as a private right, so that any prosecution to be launched against possible violations of intellectual property rights are only brought by rights holders. But in practice this does not seem to be the case, as the rights holders of pharmaceutical corporations lobby their national governments to act on their behalf, ${ }^{222}$ to either exert pressure on such national governments seeking changes or use the TRIPS-plus route to increase the level of patent protection. This is achieved through the incorporation of TRIPS-plus provisions in free trade agreements (FTAs), which are bilateral agreements as opposed to the multilateral agreements of the WTO.

Brazil's use of the compulsory license provision is to be commended, as it was able to use the threat of granting a compulsory license to its advantage most effectively in price negotiations with transnational pharmaceutical corporations, ${ }^{223}$ which has resulted in enormous savings for its anti-AIDS programme and for the SUS. ${ }^{224}$ Besides, it has also issued compulsory license when negotiations with the rights holder failed. ${ }^{225}$ On the one hand it has used the threat as a bargaining chip, when negotiations failed it has actually invoked the provision to access affordable medicines for its health care system. But then again, Brazil came under severe pressure from the US, as it launched a dispute before the WTO on the grounds that the Brazilian patent law provisions in this regard were not consistent with the TRIPS Agreement. ${ }^{226}$ The use of the compulsory licensing provision by Brazil demonstrates both a hesitation in implementation, and a willingness to engage in negotiations before implementation. A developing country, which has the flexibilities incorporated in the TRIPS Agreements for its benefit, should be able to use it for achieving its objectives without the fear of being pressurised by developed countries, or for that matter rights holding transnational pharmaceutical corporations. The sufferers are both the patients who rely upon their health care systems and the developing countries administering them. A study carried out by the United Nations Development Programme (UNDP) points out that the minimum standards of protection for intellectual property rights to be provided by each WTO Member under the TRIPS Agreement were modelled on western legal practice and are set at a level comparable to those in the developed countries and controversial, as there is an asymmetry in the level of development and research capacities between the North and the South. ${ }^{227}$

As mentioned earlier, after signing of the TRIPS Agreement, most developing countries were in for a rude shock as the trade-off agreed between the developed nations and the developing nation could not materialise. ${ }^{228}$ The standards identified are not achievable in most

\footnotetext{
222 The use of Super 301 by the US is one such instance. See also Varella (n 136). As soon as Brazil introduced compulsory licensing provisions into its laws, the US government launched a consultation at the Dispute Settlement Body (DSU) of the WTO, on the basis that the obligation for local production imposed by the Brazilian law violated Articles 27 and 28 of the TRIPS Agreement. This could clearly be seen as a developed country acting collectively on behalf of private right holders to exert pressure on a developing country seeking to use the TRIPS flexibilities.

${ }^{223}$ Chaves, et al (n 129) 170-171.

224 Rutledge (n 146).

${ }^{225}$ CM Correa (n 125).

${ }^{226}$ CM Correa (n 125). A compromise agreement was reached between the parties. Under the compromise agreement, Brazil agreed to enter into bilateral discussions before proceeding to make use of the compulsory licensing provisions under Article 68 against a US patent holder. This is a perfect example of a State representing a private right interest holder, namely that of a pharmaceutical patent right holder before the WTO.

227 United Nations Development Program's (UNDP) Human Development Report 1999: Globalization $<$ http://hdr.undp.org/sites/default/files/reports/260/hdr_1999_en_nostats.pdf > accessed 28 March 2014. See also for a more recent update 'Human Development Report 2013 - The Rise of the South: Human Progress in a Diverse World' < http://hdr.undp.org/sites/default/files/reports/14/hdr2013_en_complete.pdf > accessed 19 April 2014. ${ }^{228}$ Dreyfuss (n 39).
} 
developing countries even in the medium-term, and the same to have been implemented through a covered Agreement of the WTO, i.e., the TRIPS Agreement had seen the developing countries wilt under the pressure of a WTO obligation. It is only fair to say that both developing countries and LDCs were not ready to embrace an international intellectual property rights regime when introduced in 1995 through the TRIPS Agreement. The worldwide statistics on patents demonstrate a dominance of developed economies in intellectual property ownership, and their dominance does not stop at the domestic level. Most patents issued in developing countries are filed by overseas interests originating from developed countries and are the property of a relatively few transnational interests. ${ }^{229}$ In most developing countries, there is strong suspicion that the TRIPS Agreement is a vehicle of a policy of 'technological protectionism' more intended at consolidating an international division of labour where the industrialized nations generate innovations and developing countries are the market for the resulting products. ${ }^{230}$ The well documented TRIPS negotiation process demonstrates that a level playing field was visibly absent during negotiations as most developing countries and LDCs either did not have the necessary knowledge economy, or the infrastructure for implementing a high standard of intellectual property rights protection, ${ }^{231}$ and in many cases both factors were absent, and hence were incapable of actually giving effect to the TRIPS Agreement into its legislation. The next point that strikes us on an analysis of Brazil's patent laws ${ }^{232}$ and the health care policies is the fundamental flaw of allowing developed nations to negotiate private rights (intellectual property rights) with access to affordable medicine, which has resulted in developing nations being dragged to the WTO, or harassed by seizure of intransit-generic-medicines destined for developing countries.

Having examined the proposed changes to the industrial property laws in Brazil, the transnational pharmaceutical patent holders and developed countries await the passing of new industrial property laws in 2014. As discussed, the changes proposed are unquestionably TRIPS compliant and will be beneficial to protect its jurisdiction from the abuse of patent evergreening. The new laws could potentially see the tightening up of the patent protection mechanism and could also see interference in its implementation from pharmaceutical patent holders, as it does not bode well for the practice of evergreening. Brazil reinvented itself when it came out of over two decades of military rule to make its mark in the international arena as a big player, while bravely implementing health policies through its constitutional right to health and ably do battle against the scourge of HIV/AIDS. It did find itself in troubled waters with an early implementation of the TRIPS Agreement. But ever since, it had fought demons within and without to maintain its commitment to the constitutional right to health and access to medicines, and anti-AIDS campaign through the use of generics medicines and its TRIPS compliant industrial property laws. The proposed changes to its industrial property laws, if implemented, will only see it strengthening its position. As demonstrated in the case of India, when implementing the TRIPS compliant patent laws in 2005, Brazil can expect such external pressure in its implementation of the proposed new laws relating to industrial property.

\footnotetext{
${ }^{229}$ Compare the worldwide statistics on patents collected by the World Intellectual Property Organization (WIPO) $<$ http://www.wipo.int/ipstats/en> accessed 28 March 2014. See also PN Ghauri and PM Rao, 'Intellectual Property, Pharmaceutical MNEs and the Developing World." Journal of World Business 44, No.2 (2009) 206215,208 . The authors note that six developed countries account for $90 \%$ of patents, with the U.S. accounting for half of the total.

${ }^{230} \mathrm{CM}$ Correa, Intellectual Property Rights, the WTO and Developing Countries: The TRIPS Agreement and Policy Options (Zed Books 2000).

${ }^{231}$ Dreyfuss (n 39).

${ }^{232}$ An analysis of the pharmaceutical patent laws of India, South Africa and Thailand (all categorised as developing countries) will likely lead one to raise similar points or conclusions, as these three jurisdictions have found the going extremely tough to see the implementation of flexibilities, with constant interference from both developed nations and transnational pharmaceutical patent holding interests.
} 


$$
\text { per }
$$


Email Acceptance Article 2

From: Indira Carr <imcarr@btinternet.com>

Reply to: Indira Carr <imcarr@btinternet.com>

Date: Thursday, 1 May 2014 at 10:05

To: Jae Sundaram <jae.sundaram@buckingham.ac.uk>

Subject: Re: Article in ICTL

Dear Jae,

Many thanks. I am sending the article off to the publishers. Look forward to receiving the third instalment.

Best wishes,

Indira

From: Jae Sundaram <jae.sundaram@buckingham.ac.uk>

To: 'Indira Carr' <imcarr@btinternet.com>

Sent: Wednesday, 30 April 2014, 13:37

Subject: RE: Article in ICTL

Dear Indira

Please find attached the reworked draft, and I am hope that I have met your queries. I have taken the opportunity to do a couple of spell checks...

On another note, I have just started work on my next piece, which I see as the final piece in the series. Time permitting (as I am expecting a deluge of exam scripts to come my way), I should be able to work on it and give it shape. I will keep you posted on any progress made.

Best regards

Jae

From: Jae Sundaram

Sent: 28 April 2014 10:45

To: INDIRA CARR

Subject: RE: Article in ICTL

Dear Indira

Many thanks for your messages. I am very pleased that you find the article interesting, and publishable. I will look into your comments, carry out any changes suggested and get back to you before Wednesday.

Best

Jae 
----- Forwarded Message -----

From: INDIRA CARR <imcarr@btinternet.com>

To: Jae Sundaram <jae.sundaram@buckingham.ac.uk>

Sent: Monday, 28 April 2014, 10:04

Subject: Re: Article in ICTL

Dear Jae,

I was down in Exeter. Not that sunny ....

I enclose a couple of comments/corrections (??) in the body of your article. Could I have the final version to send off to the publisher by Wednesday. The article is very interesting and brings an interesting dimension of compulsory licensing as a bargaining tool.

best,

Indira

From: Jae Sundaram

Sent: 21 April 2014 13:50

To: 'Indira Carr'

Subject: RE: Article in ICTL

Dear Indira

I have carried out some corrections, some arising from formatting, some on referencing, and some others grammatical. I have also changed the title of the article slightly to reflect the work carried out.

I have corrected the highlighted footnote, as I found the citation online from Taylor \& Francis website. I am attaching the revised draft for your consideration.

Best regards

Jae

From: Jae Sundaram

Sent: 19 April 2014 18:39

To: Indira Carr

Subject: RE: Article in ICTL

Dear Indira

Please find attached a draft for your perusal ( 2 copies).

As mentioned earlier the topic is the TRIPS implementation in Brazil. I took an extra day, as had formatting problems while transferring the files from my laptop to my PC, my apologies.

I have left one footnote high lighted in red, as I don't have the citation yet (its my recently published article in ICTL). I can always carry out changes after it gets published in print. Please let me know of your views.

It is my first draft and will send a more refined one in the next couple of days (with no addition to footnotes, etc). 
I look forward to hearing from you.

Best

Jae

PS: I hope you are having a relaxed Easter weekend.

From: Indira Carr [mailto:imcarr@btinternet.com]

Sent: 31 March 2014 10:04

To: Jae Sundaram

Subject: Re: Article in ICTL

Dear Jae,

I am glad that the production process went through smoothly. Don't be curtailed by word length. We have published articles of even 18000 words excluding footnotes. Ideally I would like the article by 15 th april so I can sort out the peer review process.

Look forward to receiving your article.

Best,

Indira

Sent from my iPad

On 31 Mar 2014, at 09:59, Jae Sundaram <jae.sundaram@buckingham.ac.uk> wrote:

Dear Indira

I hope you are doing well.

First of all a big thanks for all the support with the scrutiny and publication of the article on TRIPS and Indian Patent Laws. I was very impressed with the support and guidance at each stage, as responses to my queries were swift and professional.

I am currently working on a piece which can be seen as the second in the series of articles on IP Rights and TRIPS Compliance (not a follow up to the earlier one on India). This one could be slightly longer, as it analysis the implementation of TRIPS Agreement in two jurisdictions - Brazil and South Africa, both identified as developing countries. On a fair estimation, I've done a third of the work so far, and hopeful of completing the work in a few weeks time.

I would much appreciate if you could let me know the following details:

i. The closing date for submission for the next next issue of ICTL - this will help me set a realistic target date to complete the work.

ii. Word Count: Currently, I have a word count of 4,500 (not including footnote) in my draft. Please let me know the absolute maximum on word count - just to make sure the piece is kept within the word limit, and also manageable.

I look forward to hearing from you.

Best regards 
From: Jae Sundaram

Sent: 19 April 2014 18:39

To: Indira Carr

Subject: RE: Article in ICTL

Dear Indira

Please find attached a draft for your perusal (2 copies).

As mentioned earlier the topic is the TRIPS implementation in Brazil. I took an extra day, as had formatting problems while transferring the files from my laptop to my PC, my apologies.

I have left one footnote high-lighted in red, as I don't have the citation yet (its my recently published article in ICTL). I can always carry out changes after it gets published in print. Please let me know of your views.

It is my first draft and will send a more refined one in the next couple of days (with no addition to footnotes, etc).

I look forward to hearing from you.

Best

$\mathrm{Jae}$ 